Hydrology and Earth System Sciences, 9(6), 657-674 (2005) C EGU

\title{
Water and nitrogen processes along a typical water flowpath and streamwater exports from a forested catchment and changes after clear-cutting: a modelling study
}

\author{
Ari Laurén ${ }^{1}$, Leena Finér ${ }^{1}$, Harri Koivusalo², Teemu Kokkonen², Tuomo Karvonen², \\ Seppo Kellomäki ${ }^{3}$, Hannu Mannerkoski ${ }^{3}$ and Marketta Ahtiainen ${ }^{4}$ \\ ${ }^{1}$ Finnish Forest Research Institute, Joensuu Research Centre, Yliopistokatu 6, P.O. Box 68 FIN-80101 Joensuu, Finland \\ ${ }^{2}$ Laboratory of Water Resources, Helsinki University of Technology, P.O. Box 5300 FIN-02015 TKK, Finland \\ ${ }^{3}$ University of Joensuu, Faculty of Forestry, P.O. Box 111, FIN-80101 Joensuu, Finland \\ ${ }^{4}$ North Karelia Regional Environment Centre, P.O. Box 69 FIN-80101 Joensuu, Finland \\ Email for corresponding author: ari.lauren@metla.fi
}

\begin{abstract}
A two dimensional model, FEMMA, to describe water and nitrogen $(\mathrm{N})$ fluxes within and from a forested first-order catchment (Kangasvaara in Eastern Finland) was constructed by linking the most significant processes affecting the fluxes of water, ammonium, nitrate and dissolved organic nitrogen along a hillslope from the water divide to the stream. The hillslope represents the average flowpath of water in the catchment and the model was used to estimate the $\mathrm{N}$ fluxes for a catchment in eastern Finland before and after clear-cutting. The simulated results were in reasonable agreement with the nitrate, dissolved organic $\mathrm{N}$ and dissolved total $\mathrm{N}$ measurements from the study catchment and with other results in the literature. According to the simulations, the major sinks of $\mathrm{N}$ after clear-cutting were immobilisation by soil microbes, uptake by ground vegetation and sorption to soil. These sinks increased downslope from the clear-cut area, indicating the importance of an uncut buffer zone between the stream and the clear-cut area in reducing $\mathrm{N}$ exports. The buffer zone retained $76 \%$ of the $\mathrm{N}$ flux coming from the clear-cut area. Nitrification was a key process in controlling the $\mathrm{N}$ export after clear-cutting and $\mathrm{N}$ increases were mainly as nitrate. Most of the annual $\mathrm{N}$ export took place during the spring flood, when uptake of $\mathrm{N}$ by plants was minimal.
\end{abstract}

Keywords: ammonium, boreal, buffer zone, DON, FEMMA, nitrate, harvesting, watershed, catchment

\section{Introduction}

Nitrogen $(\mathrm{N})$ cycling in pristine boreal forested catchments is tight, with only minor leaching losses (Tamm, 1991). Dissolved ammonium $\left(\mathrm{NH}_{4}-\mathrm{N}\right)$, nitrate $\left(\mathrm{NO}_{3}-\mathrm{N}\right)$ and organic $\mathrm{N}$ (DON) brought into soil water by atmospheric deposition or organic matter decomposition are efficiently taken up by trees, ground vegetation and microbes. The leaching of $\mathrm{NH}_{4}-$ $\mathrm{N}$ and DON is reduced by sorption in the soil (Qualls, 2000). Nitrate, in contrast, is poorly retained by sorption and can leach to the catchment outlet. However, nitrification is small in boreal coniferous forest soils because of low $\mathrm{pH}$ and availability of $\mathrm{NH}_{4}-\mathrm{N}$ (Smolander et al.,1995; Paavolainen and Smolander, 1998). In boreal forested catchments, water draining from upland mineral soils usually flows through a mire area before reaching the outlet. This affects stream water quality and most dissolved $\mathrm{N}$ is in the form of DON (Lepistö et al., 1995; Lamontagne et al., 2000; Mattsson et al., 2003).

Disturbances in the catchment, such as thorough clearcutting and subsequent site preparation, fertilisation or increased $\mathrm{N}$ deposition, may increase dissolved $\mathrm{N}$ concentrations in the soil as well as $\mathrm{N}$ exports from the catchment (e.g. Grip, 1982; Bredemeier et al., 1998; Ahtiainen and Huttunen, 1999; Pardo et al., 2002). Increased $\mathrm{N}$ exports are detected mainly as elevated $\mathrm{NO}_{3}-\mathrm{N}$ levels in streams but elevated $\mathrm{NH}_{4}-\mathrm{N}$ levels have also been reported (Moldan and Wright, 1998a; Bäumler and Zech, 1999). However, increases in DON due to clear-cutting or increased $\mathrm{N}$ depositions are considered not to occur (Akselsson et al., 2004). 
The time lag between the disturbance and the response in the stream varies according to catchment properties. In high $\mathrm{N}$ deposition areas or in catchments with fertile soil, stream water $\mathrm{N}$ concentrations increase rather quickly, whereas in low deposition areas or in nutrient-poor catchments, the response can be delayed and small (Bredemeier et al., 1998). Although $\mathrm{N}$ export may increase many times after clearcutting (Ahtiainen and Huttunen, 1999; Pardo et al., 2002), it does not exceed the deposition inputs, except if the soils are $\mathrm{N}$ saturated (Akselsson et al., 2004).

Increased $\mathrm{N}$ leaching after clear-cutting results from changes in $\mathrm{N}$ production and assimilation and hydrological fluxes; these changes are related to the amount of decomposable organic matter, disruption in uptake of $\mathrm{N}$ by trees, cessation of the interception of $\mathrm{N}$ by the forest canopy and changes in species composition of ground vegetation and microbial populations. Hydrological changes caused by clear-cutting include increased accumulation of snow, earlier onset of snowmelt and higher snowmelt intensity and elevated groundwater table levels (Päivänen, 1982; Troendle, 1983; Whitaker et al., 2002) and increased runoff (Stednick, 1996). During the growing season both interception and transpiration decrease due to the removal of the tree stand (Calder, 1990; Buttle et al., 2000; Whitaker et al., 2002).

Clear-cutting in Fennoscandia has traditionally removed stem wood only and logging residues, left on site, containing hundreds of $\mathrm{kg}$ of $\mathrm{N} \mathrm{ha}^{-1}$ (Finér et al., 2003) are subject to decomposition by soil fauna and microbes. Although clearcutting may alter soil microbial communities (Bååth et al., 1995; Houston et al., 1998; Lindo and Visser, 2003), the consequences on net $\mathrm{N}$ mineralisation may be enhanced (Olsson et al., 1996) or reduced (Bauhus, 1996). In a litterbag experiment, Palviainen et al. (2004) found significant immobilisation of $\mathrm{N}$ by logging residues with no net release of $\mathrm{N}$ during the first years after harvesting. Yet, other studies have found increased levels of dissolved $\mathrm{N}$ in soil water after harvesting (Rosén and LundmarkThelin, 1987; Titus and Malcom, 1992; Kubin, 1995; Piirainen et al., 2002a).

Increases in $\mathrm{NH}_{4}-\mathrm{N}$ availability after clear-cutting may activate nitrification in the soil (Paavolainen and Smolander, 1998; Smolander et al., 1998). Nitrification is driven by the density and activity of the microbial community (Bengtsson et al., 2003), and shows high spatial variability (Kjønaas et al., 1998; Devito et al., 1999). Increased $\mathrm{NO}_{3}-\mathrm{N}$ availability and elevated groundwater table levels after clear-cutting can initiate denitrification (Paavolainen and Smolander, 1998) and $\mathrm{N}$ losses to the atmosphere.

After clear-cutting, ground vegetation can be a significant $\mathrm{N}$ sink (Likens et al., 1970; Fahey et al., 1991; Emmet et al., 1991; Palviainen et al., 2005) and conditions may favour grasses but suppress dwarf shrubs and mosses (Nykvist, 1997). Species favoured after clear-cutting often have high $\mathrm{N}$ content, leading to an accumulation of $\mathrm{N}$ in the ground vegetation (Fahey et al., 1991; Mou et al., 1993; Palviainen et al., 2005). However, in other studies, the logging residues have suppressed the ground vegetation (Nykvist, 1971; Fahey et al., 1991). Assimilation into soil microbes and chemical sorption by the soil has resulted in soil becoming a significant sink of $\mathrm{N}$ after timber harvesting (Kjønaas et al., 1998; Lamontagne et al., 2000; Vestgarden et al., 2003).

During transport of dissolved $\mathrm{N}$ to the stream, different soil and vegetation types and microbial populations are encountered and all may control the form and levels of $\mathrm{N}$ reaching the stream. Clearly, the flow path is significant in controlling the $\mathrm{N}$ load to a stream (Devito et al., 1999; Jacks and Norrström, 2004). The use of uncut buffer zones between a clear-cut area and receiving surface waters is based on the idea that denitrification and $\mathrm{N}$ retention by microbes, vegetation and soil occurs along the flow path taken. While buffer zones have been shown to decrease $\mathrm{N}$ exports to watercourses (e.g. Ahtiainen and Huttunen, 1999), there is only weak evidence of an increase in N uptake by trees in the buffer zone (Lundell and Albrektson, 1997). However, experiments in Sweden found retention of a significant proportion of $\mathrm{N}$ leached from a clear-cut area in a 10-30 m wide peatland buffer zone (Jacks and Norrström, 2004).

The export of $\mathrm{N}$ to streams is controlled by complex physical, chemical and biological interactions. Several models have been used to describe the water and $\mathrm{N}$ dynamics of a catchment, e.g. MAGIC and its versions (Jenkins et al., 1997; Wright et al., 1998a; Krám et al., 2001; Jenkins et al., 2001), SOILN (Eckersten et al., 1995; Eckersten and Beier, 1998), SMART and its versions (Ahonen et al., 1998; Kämäri et al., 1998), MERLIN (Kjønaas and Wright, 1998; Wright et al., 1998b) and pnet-CN/CHESS (Postek et al., 1995). In these models, the water and $\mathrm{N}$ fluxes for a forest stand or an entire catchment are either calculated in a forested vertical column of soil divided into horizontal layers, or the modelling domain is described as a set of interconnected storages with no dimensions specified. For large catchments, various semi-distributed models have been applied, such as INCA (Whitehead et al., 1998; Wade et al., 2002; Langusch and Matzner, 2002), SWAT and related models (Krysanova et al., 1998; Francos et al., 2001) and HBV-N (Arheimer and Wittgren, 2002). In these models the focus has been on producing water and $\mathrm{N}$ dynamics for large river basins and process descriptions have been less detailed than in the point-scale models. In none of the approaches is the downslope routing of $\mathrm{N}$ through different 
land-use types possible, therefore, they do not allow the assessment of how the location of a clear-cut area in the catchment affects the $\mathrm{N}$ export to the stream. Furthermore, none of the models accounts explicitly for fluxes of DON, even though DON can comprise $80-90 \%$ of stream export loads of Dissolved Total Nitrogen (DTN) in boreal forested catchments. In Finland and Sweden, an uncut buffer zone is required between a clear-cut area and the stream to reduce nutrient leaching. Clearly, the dimensions of the buffer zone must be optimised to minimise the loading to streams while maximising returns from harvesting.

To account for the most significant water and $\mathrm{N}$ fluxes in forested first-order catchments, a mathematical model (FEMMA) was constructed; this allowed evaluation of the effect of location of clear-cutting on stream water $\mathrm{N}$ export. The catchment was simplified into a two-dimensional hillslope extending from the water divide to the outlet. FEMMA was applied and parameterised for boreal nitrogenlimited, low $\mathrm{N}$ deposition conditions. In this study, FEMMA was applied to the Kangasvaara catchment for five years before and after clear-cutting to quantify the effects of clearcutting on:

(i) the $\mathrm{N}$ fluxes $\left(\mathrm{NO}_{3}-\mathrm{N}, \mathrm{NH}_{4}-\mathrm{N}\right.$ and $\left.\mathrm{DON}\right)$ within forest, clear-cut and buffer zone compartments, (ii) $\mathrm{N}$ export to the stream, and

(iii) to identify the dominant factors and processes.

By assessing mass balances for $\mathrm{N}$ fluxes in forest, clearcut and buffer zone compartments along the hillslope, the significance of the buffer zone was evaluated.

\section{Material and methods}

\section{STUDY AREA}

Kangasvaara, a forested first-order, research catchment of 56 ha in Eastern Finland ( $63^{\circ} 51^{\prime}$ N, $28^{\circ} 58^{\prime}$ E, Fig. 1), was studied intensively in an investigation of the effects of clearcutting on water quality (Finér et al., 1997). Elevations in the catchment range from 187 to 238 metres a.s.l. Longterm mean annual precipitation and air temperature in the area are $700 \mathrm{~mm}$ and $1.5^{\circ} \mathrm{C}$, respectively. Most of the catchment $(92 \%)$ is covered with upland mineral soil, while the rest is pristine forested peatland bordering the catchment stream. The mineral soil, mainly Haplic Podzols (FAO, 1988 ) is developed on sandy till between 0.9 to $2.1 \mathrm{~m}$ thickness with a fine earth clay content of less than $2 \%$. The underlying bedrock is granodiorite and the site type is classified as medium rich Vaccinium-Myrtillus according

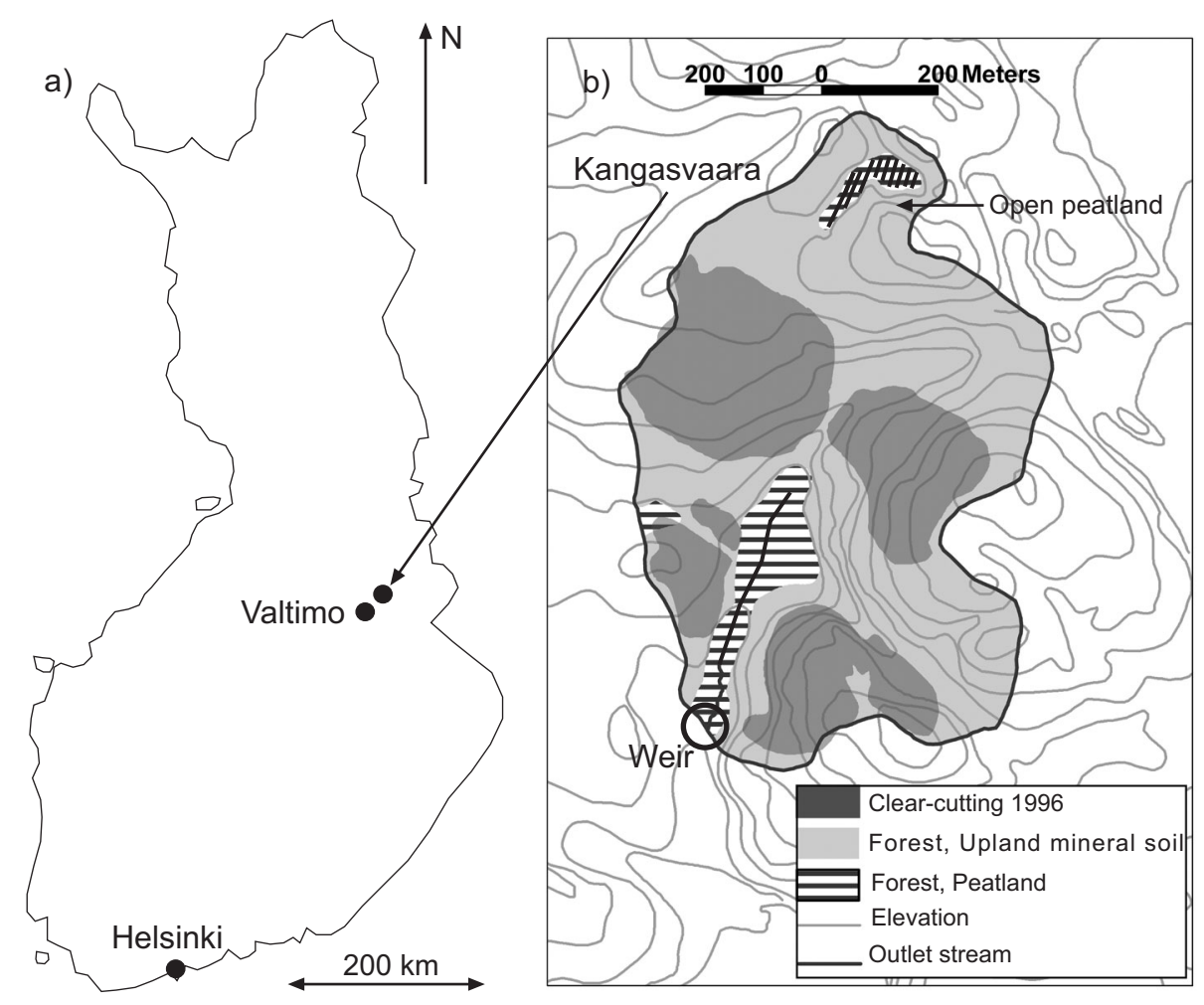

Fig. 1. (a) Location and (b) experimental setup of the Kangasvaara cathment in Eastern Finland. 
to the Finnish classification (Cajander, 1949). The forests on the mineral soil are old-growth Norway spruce (Picea abies (L.) Karsten) mixed with Scots pine (Pinus sylvestris L.), silver birch (Betula pubenscens Ehrh. and B. pendula Roth.) and European aspen (Populus tremula L.) (Finér et al.,1997). The mean stem volume of the stands is $275 \mathrm{~m}^{3}$ $\mathrm{ha}^{-1}$. The peatland area consists of pristine mesotrophic spruce-dominated mires.

In August-October 1996, five compartments totalling 19 ha of the upland mineral soil forest area were clear-cut and stems were removed $\left(239 \mathrm{~m}^{3} \mathrm{ha}^{-1}\right)$ (Fig. 1). Uncut buffer zones were left between the clear-cut area and the stream (Finér et al., 2003). In August 1998, the soil was disc ploughed in strips to facilitate forest regeneration and in spring 1999 Scots pine seedlings were planted.

\section{EXPERIMENTAL DATA USED}

Several experimental datasets from the Kangasvaara catchment were used to construct and calibrate FEMMA. Hourly meteorological measurements of air temperature, relative humidity, global radiation, wind speed and precipitation since 1992 were combined with records from the nearest (c. $20 \mathrm{~km}$, Valtimo) weather station operated by the Finnish Meteorological Institute (Koivusalo et al., 2005).

Daily runoff measurements from a V-notch weir were available for five years before (1992-1996) and after clearcutting (1997-2001) (Finér et al., 1997). Concentrations of $\mathrm{N}$ were measured from water samples taken from the weir at two-week intervals during spring and autumn, and monthly in summer and winter. The $\mathrm{N}$ fractions were $\mathrm{NH}_{4}-\mathrm{N}$, combined nitrite- $\mathrm{N}$ and nitrate- $\mathrm{N}$ (referred to here as $\mathrm{NO}_{3}-\mathrm{N}$ ) and dissolved total $\mathrm{N}$ (DTN) (Finér et al., 1997). DTN was analysed from unfiltered water samples. DON was calculated by subtracting the inorganic $\mathrm{N}$ fractions $\left(\mathrm{NH}_{4}-\mathrm{N}\right.$ and $\left.\mathrm{NO}_{3}-\mathrm{N}\right)$ from DTN. Monthly exports of N were calculated using a discharge-weighted method described by Rekolainen et al. (1991).

For the development and calibration of the decomposition sub-model included in FEMMA the results of litterbag experiments (Palviainen et al.,2004) were used; these included the annual mass loss and $\mathrm{N}$ content of branch, leaf and fine root logging residues for three consecutive years after clear-cutting. For ground vegetation dynamics, the fiveyear dataset of Palviainen et al. (2005) was used.

Spatial data on elevation and soil depths were obtained by the Geological Survey of Finland using a Global Positioning System (GPS) and ground penetrating radar along a systematic network of transects at $70-120 \mathrm{~m}$ intervals. Elevation of the soil surface and depth of soil were calculated on a $10 \times 10 \mathrm{~m}^{2}$ grid using geo-statistical interpolation. Soil hydraulic characteristics used in the model were taken from Koivusalo et al. (2005).

\section{DESIGN AND PARAMETERISATION OF FEMMA}

\section{Overall structure}

The FEMMA model combined and modified existing models with new ones (Fig. 2). Hydrological fluxes are described for canopy and snow accumulation and melt (Canopy and snow model, Koivusalo et al., 2001) and water fluxes and storages along the hillslope (Characteristic profile model, Karvonen et al., 1999). Tree-stand net photosynthesis and production of litter are described with FINNFOR (Kellomäki and Väisänen, 1997) and the decomposition of organic matter with ROMULN. Nitrification and denitrification are calculated with models presented in Jansson and Karlberg (2001). N uptake, transport with surface and ground waters, retention by soil and immobilisation in litter and logging residues are also simulated.

The catchment is described as a two-dimensional hillslope (Fig. 3), which is a longitudinal section extending from the water divide to the stream and from the soil surface down to the bedrock. The hillslope is divided into compartments distinguishing different site and soil types, stand characteristics or treatments in the catchment. Above-ground hydrological processes and forest dynamics are simulated separately for each compartment. For calculation of the processes in the soil, the hillslope is divided into vertical columns and the columns subdivided into horizontal layers. The transport of water and $\mathrm{N}$ between the layers and the columns is calculated. The hillslope is formed from a digital elevation model (DEM) to represent typical flowpaths of water inside the catchment (Kokkonen et al., 2001). Water and associated $\mathrm{N}$ fluxes leaving the hillslope feed into a linear storage, which represents retention in a stream. A daily time step is used.

\section{Two-dimensional description of the catchment}

The surface boundary of the hillslope was calculated as the mean elevation difference between DEM pixels and its receiving stream pixel at a given distance range along the flowpath. For each distance range, the mean soil depth was determined from the interpolated soil depth grid. The number of pixels located at a given distance along the profile is used to calculate the relative width for the hillslope (Shreve, 1969). The location and proportion of forest, clear-cutting and buffer zone compartments along the hillslope were similarly assigned according the distribution of pixels (Fig. 3). The forest stand characteristics for forest and buffer zone compartments were determined according to field observations (Table 1). Peatland and mineral soil areas along 


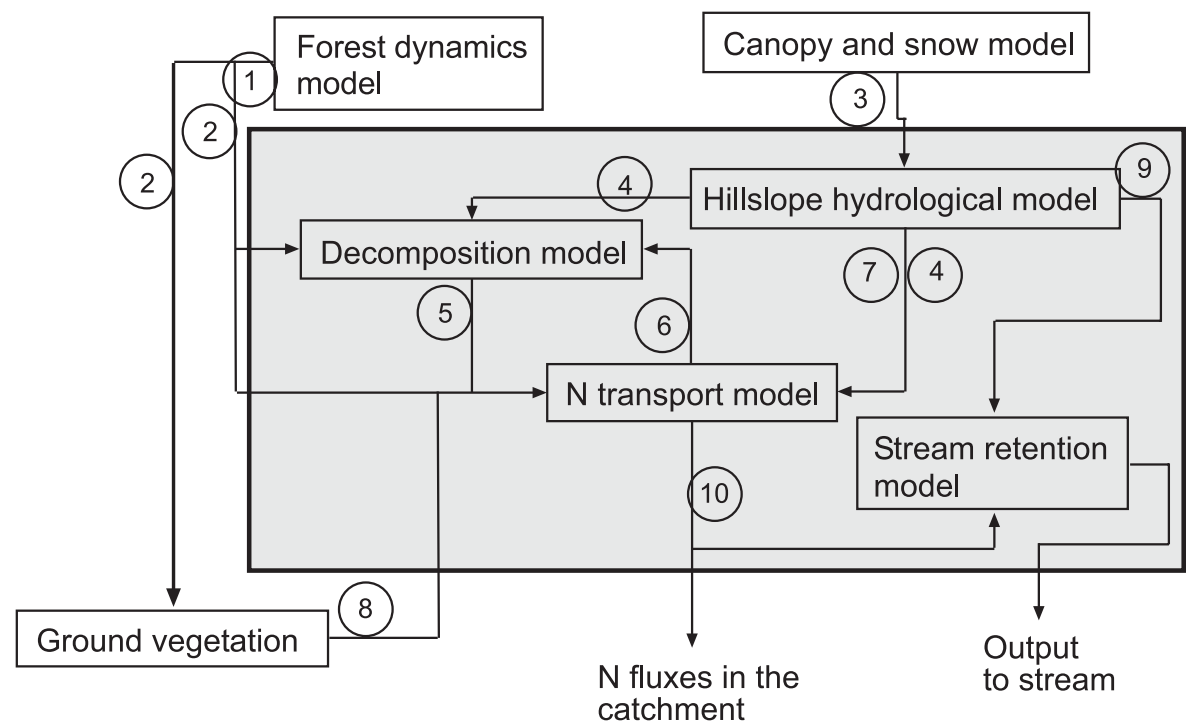

Litter input

(1) Surface litter moisture Soil temperature

(5) Release of $\mathrm{N}$

(8) Net photosynthesis dynamics

2 Net photosynthesis dynamics for trees

(6) Immobilisation of $\mathrm{N}$ for ground vegetation

(3) Water input to soil

(4) Water content in soil
(7) Water fluxes columns

Water fluxes

to stream

(10) N fluxes to stream

Dynamics calculated inside same time step

Fig. 2. Overall structure of the FEMMA model and the variables transferred between the sub-models. The sub-models inside the grey box are integrated into same calculation routine and computed inside one time step

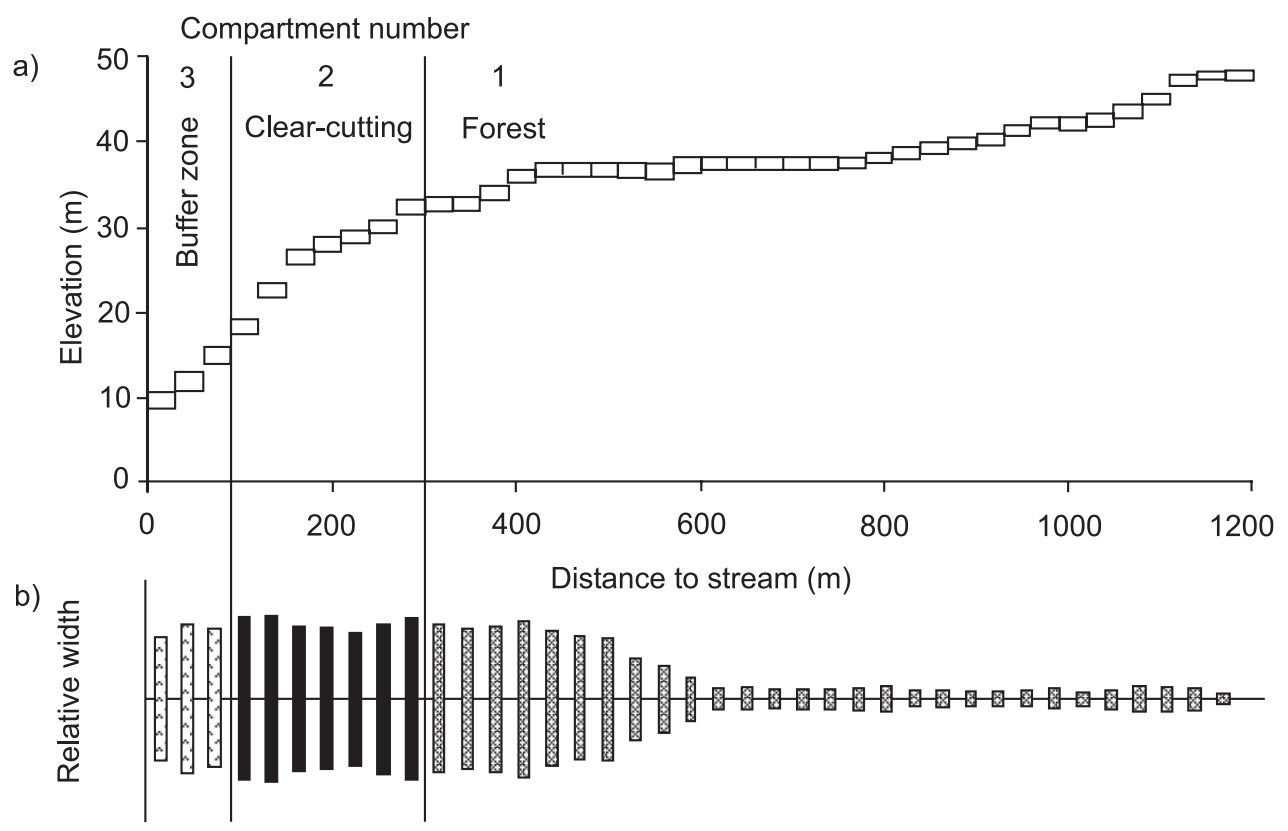

Fig. 3. (a) Elevation and (b) relative width of the hillslope representing the Kangasvaara catchment. The profile consists of 40 columns of $30 \mathrm{~m}$ length and depth to bedrock ranging from 0.9 to $2.1 \mathrm{~m}$. Three compartments describing forest stand, site type and soil type are identified: 1 mature Norway spruce on upland mineral soil, 2 - same as 1 but clear-cutting from October 1996, 3-uncut buffer zone between the stream and the clear-cutting comprising of mature Norway spruce on upland mineral soil and peatland. The relative cover of each compartment type within the catchment was 0.51 for Compartment 1, 0.35 for Compartment 2 and 0.14 for Compartment 3. 
Table 1. Forest stand characteristics in Kangasvaara catchment. These were used as input variables for the FINNFOR model applied for the forest and the buffer zone compartments.

\begin{tabular}{|c|c|c|c|c|c|}
\hline Stratum & Tree species & $\begin{array}{l}\text { Mean breast height diameter, } \\
\mathrm{cm}\end{array}$ & $\begin{array}{l}\text { Mean height, } \\
m\end{array}$ & $\begin{array}{l}\text { Age, } \\
a\end{array}$ & $\begin{array}{l}\text { Stem density, } \\
\text { stems } \text { ha }^{-1}\end{array}$ \\
\hline Dominant layer & Picea abies & 21 & 18 & 130 & 800 \\
\hline Suppressed & Picea abies & 10 & 9 & 100 & 800 \\
\hline
\end{tabular}

the profile are also assigned based on the spatial distribution of these two soil types at a given distance from the stream. For Kangasvaara, the profile was discretised into $30 \mathrm{~m}$ long columns, which yielded a total of 40 columns. Further explanation of how the characteristic profile is determined is described by Koivusalo et al. (2005).

\section{Above-ground hydrology}

Above-ground hydrology is simulated in one dimension for each compartment present in the hillslope profile. The canopy routine simulates solar radiation, long-wave radiation and wind speed beneath the canopy and throughfall amount from meteorological variables characterising conditions above the canopy (Koivusalo and Kokkonen, 2002). Relative humidity and air temperature are assumed not to be affected by the canopy. The snow routine was based on the energy balance approach (Koivusalo et al., 2001). Canopy and snow routine was run at an hourly time step. The parameterisation of the canopy and snow model for Kangasvaara has been described by in detail by Koivusalo et al. (2005).

\section{Net photosynthesis and litter-fall production}

Tree-stand net photosynthesis, litter production and soil temperature at different depths were calculated for each forest compartment using the FINNFOR-model (Kellomäki and Väisänen, 1997) at an hourly time-step. FINNFOR was parameterised for dominant and suppressed tree strata according to field measurements at Kangasvaara (Table 1). FINNFOR also produced estimates of annual litter-fall production and $\mathrm{N}$ contents for five fractions: branches, fine roots, foliage, roots and stems. To provide daily litter-fall inputs for the organic matter decomposition model, the annual litter-fall values was distributed for the period from September to October and for two weeks in May, which represented the litter-fall accumulated on snow. For other days litter-fall were considered to be zero.

Ground vegetation biomass and $\mathrm{N}$ pools dynamics were calculated from experimental data from Kangasvaara. Above-ground biomass and $\mathrm{N}$ concentrations of mosses, blueberry (Vaccinium myrtillus L.), lingonberry (V. vitisidae $\mathrm{L}$.), grasses and herbs, and the roots of all the species, have been determined before and after clear-cutting (Palviainen et al., 2005). To represent the daily net photosynthesis of the ground vegetation, that of the treestand simulated with FINNFOR was scaled to match the ground vegetation biomass measurements. The annual litter production of the ground vegetation was estimated from the measured biomass according to biomass /litter-fall ratios presented by Mälkönen (1974). For the decomposition model, the ground vegetation litter-fall production estimates and their $\mathrm{N}$ contents were combined with the FINNFOR foliage and fine root litter production values. Daily litterfall was then obtained by distributing the annual values to the period from September to October.

The ground vegetation dynamics were further modified to include the effect of site preparation on $\mathrm{N}$ dynamics. The area of soil where mineral soil was exposed or where the vegetation was covered with soil in disc ploughing was estimated to be $40 \%$ at Kangasvaara and the vegetation which died was transferred to the decomposition model. Vegetation on the area of soil remaining intact is assumed to develop and produce litter-fall.

\section{Water fluxes along hillslope}

Soil water movement down the hillslope and runoff generation were simulated with the characteristic profile model, CPM (Karvonen et al., 1999; Koivusalo and Kokkonen, 2003). CPM takes input daily throughfall/ snowmelt and potential transpiration values aggregated from the hourly output from the canopy and snow models. CPM is a quasi-two-dimensional model in the sense that vertical and lateral water fluxes were computed alternately. Vertical fluxes in all columns of the hillslope were computed using an approximation of the Richards equation with successive steady-state solutions of the pressure head distribution (Skaggs, 1980). Infiltration into a soil column is controlled by the available air-filled pore volume in the column. Water that does not infiltrate is transported downslope and infiltrates into the next column further down the slope if pore volume allows, or to the stream (surface runoff).

After the vertical fluxes and the resulting groundwater levels have been resolved, the lateral groundwater flows between vertical soil columns are computed according to 
Darcy's law. Groundwater flow from the column next to the stream constitutes the baseflow component. When groundwater level in any column rises above the soil surface, water flows downslope as exfiltration. The sum of all runoff components (surface runoff, exfiltration and baseflow) is passed through a linear storage, which describes the delay of water flowing in the stream. Detailed parameterisation of CPM for Kangasvaara catchment is presented by Koivusalo et al. (2005).

\section{Organic matter decomposition and $N$ mineralisation}

Organic matter decomposition was simulated with a routine modified from the ROMUL model (Chertov et al., 2001). ROMUL was developed for forest soils having a raw humus (mor), moder or mull humus forms (Klinka et al., 1981). Decomposition is modelled in three different stages: fresh litter material (L), complex humic substances with undecomposed organic debris (F) and humus material $(\mathrm{H})$ (Chertov and Komarov, 1997).

In ROMUL, the release of $\mathrm{N}$ is remarkably lower than that of carbon, describing the high rate of $\mathrm{N}$ consumption by micro-organisms. However, ROMUL does not account for such $\mathrm{N}$ immobilisation by micro-organisms, which actually increases the absolute $\mathrm{N}$ content above the initial amount of $\mathrm{N}$ in the decaying litter cohorts (Berg and Söderström, 1979; Berg and Staaf, 1981; Staaf and Berg, 1982; Berg and Theander, 1984; Berg, 1988; Hasegava and Takeda, 1996; Gebauer et al., 2000; Palviainen et al., 2004).

The original structure of ROMUL was modified such that the $\mathrm{N}$ dynamics would include immobilisation as described above but representation of the carbon dynamics was not changed. The modified ROMUL is referred to as ROMULN. The $\mathrm{N}$ immobilisation was modelled according to the following principles:

(1) The dynamics of soil micro-organisms were modelled implicitly by including the immobilised $\mathrm{N}$ in the soil organic matter $\mathrm{N}$ pool.

(2) Immobilisation occurs when the combined concentration of $\mathrm{N}$ in $\mathrm{L}$ and $\mathrm{F}$ pools falls below a critical concentration level, which is given as a parameter for each litter fraction (e.g. Kirschbaum and Paul, 2002), and when the soil temperature is above $0^{\circ} \mathrm{C}$. The immobilisation $\mathrm{N}$ demand is calculated as $\mathrm{N}$ deficit with respect to critical concentration.

(3) $\mathrm{N}$ for the immobilisation was extracted from the pool of dissolved N (e.g. Molina et al., 1983; Li et al., 1992; Kirschbaum and Paul, 2002). Immobilised N was taken to the $\mathrm{F}$ pool. The Mf parameter used in original ROMUL (Chertov et al., 2001) to slow the release of $\mathrm{N}$ from $\mathrm{F}$ pool was set to 1.0 .
Table 2. Parameter values in the ROMULN soil organic matter decomposition model

\begin{tabular}{llll}
\hline Parameter & Unit & Value & Determined \\
\hline $\begin{array}{l}\text { Organic matter } \\
\text { content in mineral soil }\end{array}$ & \% grav. & 3.6 & $\begin{array}{l}\text { fixed } \text { a priori } \\
\text { fixed } \text { a priori }\end{array}$ \\
$\begin{array}{l}\text { Ash concentration of litter } \\
\text { Critical concentration in }\end{array}$ & $\%$ grav. & 2 & \\
$\begin{array}{l}\text { branches } \\
\text { fine roots }\end{array}$ & $\% \mathrm{~N}$ & 0.5 & calibrated \\
foliage & from & 1.9 & $\begin{array}{l}\text { calibrated } \\
\text { roots } \\
\text { stems }\end{array}$ \\
\hline
\end{tabular}

ROMUL requires gravimetric water contents to simulate decomposition rates. The calculation of the gravimetric water contents from volumetric water contents and bulk densities is rather sensitive to the bulk density of the soil. To reduce this sensitivity and to ensure restriction of decomposition under wet conditions, an extra control was added to ROMULN. When the air-filled porosity $\left(\mathrm{e}_{\mathrm{A}}\right.$, in volumetric $\%$ ) in soil was lower than $15 \%$ of volume, the water content functions (denoted g1-g6 in Chertov et al., $2001)$ were multiplied by $\left(1-\left(15-e_{A}\right) / 15\right)$, on the basis of experimental results that soil respiratory activity connected with decomposition decreased when $\mathrm{e}_{\mathrm{A}}$ fell below 10-20\% of the soil volume (Glinski and Stepniewski, 1985)

ROMULN was integrated with the CPM and FemmaN (described later) at the top of each column along the hillslope. ROMULN receives the daily water contents in mineral topsoil from the CPM-model, daily moisture contents in the above-ground organic matter, soil temperature, litter-fall production and $\mathrm{N}$ inputs (for branches, fine roots, foliage, roots and stems) from the FINNFOR-model output, and for the ground vegetation, as described earlier, and microbiologically immobilised $\mathrm{N}$ from FemmaN -model (see Fig. 2). N released from organic matter computed by ROMULN is considered to be dissolved total $\mathrm{N}$ (DTN), and is subsequently used as input to the FemmaN -solute transport model. ROMULN was run at daily time step. Parameterisation of ROMULN for Kangasvaara is presented in Table 2.

\section{Nitrogen fluxes along hillslope}

The transport of different $\mathrm{N}$ fractions down the hillslope was calculated with a two-dimensional solute transport model, FemmaN. The modelled $\mathrm{N}$ fractions are $\mathrm{NH}_{4}-\mathrm{N}, \mathrm{NO}_{3}-$ $\mathrm{N}, \mathrm{DON}$ and DTN (the sum of the former three fractions). The time step used for FemmaN is one day. 
$\mathrm{N}$ pools are calculated for each column and layer along the hillslope (Fig. 3). For forest, $\mathrm{NH}_{4}-\mathrm{N}, \mathrm{NO}_{3}-\mathrm{N}$ and DON deposition inputs were calculated from the observed mean concentrations for throughfall at Kangasvaara (Piirainen et al., 1998; Piirainen et al., 2002a) and from water input to the soil surface calculated with the Canopy and SnowModel (Fig. 2). For the clear-cut area the concentration for the deposition was taken from the measured bulk precipitation data. The daily $\mathrm{N}$ input to soil arising from the decomposition of organic matter was received from ROMULN output. ROMULN DTN values were divided into $\mathrm{NH}_{4}-\mathrm{N}$ and DON fractions (Table 3); $\mathrm{NO}_{3}-\mathrm{N}$ was assumed not to be formed in decomposition. The majority of DTN was assumed to be $\mathrm{NH}_{4}-\mathrm{N}$ for mineral soil columns and DON for peatland columns (Hannam and Prescott, 2003; Potila and Sarjala, 2004).

The horizontal and vertical transport of $\mathrm{N}$ through the soil was calculated by the method of Jansson and Karlberg (2001). Retention of $\mathrm{NH}_{4}-\mathrm{N}$ and $\mathrm{NO}_{3}-\mathrm{N}$ was computed with layer-specific adsorption coefficients taken from Jansson

Table 3. Parameters for FemmaN -model.

\begin{tabular}{|c|c|c|c|}
\hline Parameter & Unit & Value & Determined \\
\hline \multicolumn{4}{|l|}{ Nutrient use ratio (NUE) } \\
\hline trees & $\mathrm{kgC} / \mathrm{kgN}$ & 125 & fixed a priori \\
\hline ground vegetation & $\mathrm{kgC} / \mathrm{kgN}$ & 60 & fixed a priori \\
\hline \multicolumn{4}{|l|}{ Nitrification model } \\
\hline $\mathrm{npH}$ & {$[-]$} & 0.125 & fixed a priori \\
\hline nrate & {$[-]$} & 0.2 & calibrated \\
\hline nrate (clear-cut compartme & nt) $[-]$ & 0.1 & calibrated \\
\hline
\end{tabular}

Fractioning of released DTN

mineral soil

$\begin{array}{llll}\mathrm{NH}_{4}-\mathrm{N} & \% & 95 & \text { calibrated } \\ \text { DON } & \% & 5 & \text { calibrated } \\ \text { peat soil } & & & \\ \mathrm{NH}_{4}-\mathrm{N} & \% & 50 & \text { calibrated } \\ \text { DON } & \% & 50 & \text { calibrated }\end{array}$

Adsorption coefficients mineral soil

$\begin{array}{llll}\mathrm{NH}_{4}-\mathrm{N} & {[-]} & 0.99 & \text { fixed } \text { a priori } \\ \mathrm{NO}_{3}-\mathrm{N} & {[-]} & 0.0 & \text { fixed } \text { a priori } \\ \text { DON } & {[-]} & 0.99 & \text { calibrated }\end{array}$

\begin{tabular}{clll} 
peat soil & & & \\
$\mathrm{NH}_{4}-\mathrm{N}$ & {$[-]$} & 0.99 & fixed $a$ priori \\
$\mathrm{NO}_{3}-\mathrm{N}$ & {$[-]$} & 0.0 & fixed $a$ priori \\
$\mathrm{DON}$ & {$[-]$} & 0.75 & calibrated \\
\hline
\end{tabular}

and Karlberg (2001) (Table 3). DON can be retained in both mineral and peat soils (Qualls, 2000) but adsorption coefficients for DON are not available and values were calibrated. Nitrification and denitrification fluxes were calculated as a function of soil $\mathrm{NH}_{4}-\mathrm{N}$ and $\mathrm{NO}_{3}-\mathrm{N}$ concentrations and of temperature and moisture for each soil layer (Jansson and Karlberg, 2001). In forest soils the rate of nitrification is often reduced by low $\mathrm{pH}$ (e.g. Persson and Wirén, 1995; Persson et al., 2000). The reduction factor for nitrification $(\mathrm{npH})$ was calculated using Eqn. 1 (Wu and McGechan, 1998):

$$
\mathrm{npH}=(\mathrm{pH}-\mathrm{pHmin}) /(\mathrm{pHmax}-\mathrm{pHmin})
$$

where $\mathrm{pH}$ is the actual $\mathrm{pH}$ value of the soil, $\mathrm{pHmax}$ is the $\mathrm{pH}$ value at which nitrification is not affected by the acidity and $\mathrm{pHmin}$ is the value at which nitrification is zero. The soil $\mathrm{pH}$-values are 4.0 and 4.2 for the organic and mineral soil layers respectively (Piirainen et al., 2002b). A value of 3.8 for $\mathrm{pHmin}$ and 5.4 for $\mathrm{pHmax}$ was based on data presented by Persson et al. (2000).

Gaseous $\mathrm{N}_{2} \mathrm{O}-\mathrm{N}$ fluxes

$\mathrm{N}_{2} \mathrm{O}-\mathrm{N}$ can be produced by nitrification, although it is usually considered to be produced during denitrification (Ambus, 1998). However, in laboratory experiments, Martikainen (1985) has shown that nitrification in acid forest soil may release substantial amounts of $\mathrm{N}_{2} \mathrm{O}-\mathrm{N}$. When soil $\mathrm{pH}$ (in water solution) was less than $4.1,20 \%$ of the oxidised $\mathrm{NH}_{4}-\mathrm{N}$ was converted into $\mathrm{N}_{2} \mathrm{O}-\mathrm{N}$. The percentage $\left(\mathrm{P}_{\mathrm{N} 2 \mathrm{O}-\mathrm{N}}\right)$ of the oxidised $\mathrm{NH}_{4}-\mathrm{N}$ becoming $\mathrm{N}_{2} \mathrm{O}-\mathrm{N}$ instead of $\mathrm{NO}_{3}-\mathrm{N}$ was estimated using Eqn. 2 (Martikainen, 1985):

$$
\mathrm{P}_{\mathrm{N} 2 \mathrm{O}-\mathrm{N}}=\operatorname{Min}\left(20.0,10^{\left(-2.387^{\prime} \mathrm{pH}+11.184\right)}\right) .
$$

\section{Plant $N$ uptake}

The $\mathrm{N}$ demand of the uptake by trees was calculated from the modelled daily net photosynthesis values by dividing it by the nutrient use efficiency, NUE (Gourley et al., 1994). The NUE (Table 3) was calculated from forest biomass and nutrient content data presented by Finér et al. (2003) for Kangasvaara. The NUE for the ground vegetation was calculated for Kangasvaara from measured biomass and $\mathrm{N}$ contents (Palviainen et al., 2005).

Trees and ground vegetation take up $\mathrm{N}$ from the whole rooting zone (depth $30 \mathrm{~cm}$ ), whereas the microbes take up $\mathrm{N}$ only from the top soil layer $(10 \mathrm{~cm})$. The plants and microbes preferably take up inorganic forms of $\mathrm{N}\left(\mathrm{NH}_{4}-\mathrm{N}\right.$ and $\mathrm{NO}_{3}-\mathrm{N}$ ) but, if the inorganic $\mathrm{N}$ pool is insufficient, then DON is also taken up. DON contains amino acids, which for arctic plants may account for $10-82 \%$ of the total $\mathrm{N}$ 
uptake (Kielland, 1994). Näsholm et al. (1998) has shown that certain boreal forest tree species (e.g. P. sylvestris, $P$. abies), dwarf shrubs (e.g. V. myrtillus) and grass (e.g. Deschampsia fexuosa) also take up amino acids. However, amino acids comprise only some $1-1.5 \%$ of the DON in soil water (Hannam and Prescott, 2003); therefore, the DON uptake was restricted to a maximum of $1 \%$ of the current DON storage. The vertical distribution of $\mathrm{N}$ uptake in a column was taken to correspond to the relative abundance of $\mathrm{N}$ in each soil layer within the rooting zone.

\section{CALIBRATION}

Parameters for the hydrological model were calibrated to Kangasvaara (Koivusalo et al., 2005). In calibrating the FemmaN -model, all the measured $\mathrm{N}$ concentrations in the outlet stream were used and so the model could not be validated against streamwater chemistry. Those parameter values presented in literature were fixed a priori. The calibrated parameters included nrate parameter (nitrification in optimal conditions) in the nitrification model for the clearcutting area, DON adsorption parameter for mineral and peat soils and fractioning parameter for DTN released in the decomposition. Parameters for the critical concentration in ROMULN-model were calibrated against litterbag experiments presented in Palviainen et al. (2004).

\section{NITROGEN FLUX SIMULATIONS}

Simulations were performed for the period starting from January 1, 1992, to December 31, 2001, using two scenarios, one represented the reality, in which clear-cutting (October 1996) and site preparation (August 1998) in the catchment had been carried out. The other scenario was a control without any treatments. The difference represented the effect of the clear-cutting and site preparation. Daily time series of runoff and concentrations and export of $\mathrm{NO}_{3}-\mathrm{N}, \mathrm{NH}_{4}-\mathrm{N}$ and DON in the stream were computed and compared against field measurements.

The $\mathrm{N}$ mass balance for the forested, clear-cut and buffer zone compartments in the catchment (denoted as 1-3 in Fig. 3 ) were also computed. For each compartment, the influxes were the ground- and surface-water influxes from upslope, and the deposition and decomposition $\mathrm{N}$ flux; the outfluxes were the ground- and surface-water outflux downslope, and tree and ground vegetation uptake, microbial immobilisation, denitrification and emissions of $\mathrm{N}_{2} \mathrm{O}-\mathrm{N}$. The change in the adsorption storage of the soil was calculated. Each flux was calculated for $\mathrm{NH}_{4}-\mathrm{N}, \mathrm{NO}_{3}-\mathrm{N}$ and for DON.

The goodness of fit between modelled and measured values was assessed in terms of the mean absolute error
(ME):

$$
M E=\frac{\sum_{i}\left|x_{i}-m_{i}\right|}{n}
$$

where $x_{i}$ is the simulated value at time $i, m_{i}$ is the measured value, and $n$ is number of the measurements in the time series. The goodness of fit was also assessed by correlation analysis of the measured and calculated time series.

\section{Results}

\section{OUTPUT TO STREAM}

\section{Nitrogen concentrations}

The FEMMA-model enabled reproduction of the seasonal and treatment-induced changes in streamwater $\mathrm{N}$ concentrations (Fig. 4). Calculated DTN concentrations were higher in summer than in winter, following the pattern of the measured concentrations (Fig. 4). For DTN, the ME was slightly less than half the measured mean concentration (Table 4). DON was the dominant form of $\mathrm{N}$ in streamwater, accounting for $90 \%$ of DTN on average, according to both calculations and measurements. Thus, the temporal pattern in DON concentrations and the goodness of fit of the model were rather similar to that for DTN. The simulations also reproduced the seasonal pattern in $\mathrm{NO}_{3}-\mathrm{N}$ concentrations; the annual maxima occurred before the spring flood and decreased thereafter. Measured concentrations of $\mathrm{NH}_{4}-\mathrm{N}$ in the stream showed no distinctive seasonal variation and were low, being only slightly above detection limit concentrations throughout the year. There was no correlation between the measured and calculated $\mathrm{NH}_{4}-\mathrm{N}$ concentrations.

The effects of clear-cutting in August-October 1996 indicated no change in the seasonal pattern of $\mathrm{N}$ concentrations until autumn 1999, when $\mathrm{NO}_{3}-\mathrm{N}$ concentrations began to increase. This was in accordance with the measurements (Fig. 4). The increase in $\mathrm{NO}_{3}-\mathrm{N}$ concentrations was the most distinctive effect of clearcutting. However, DON and $\mathrm{NH}_{4}-\mathrm{N}$ concentrations also increased during 2000. The increase in DON concentrations was slightly less than for $\mathrm{NO}_{3}-\mathrm{N}$ but the relative increase was rather small.

\section{Nitrogen export to the stream}

The FEMMA-model mimicked the monthly and annual export of $\mathrm{N}$ to the stream with reasonable accuracy (Fig. 5, Table 4), compared with measurements (Table 5). N export values induced by clear-cutting increased in spring 1997 but remained low until spring 2000. The greatest $\mathrm{N}$ export was calculated for 2000 and, during 2001, N export started 


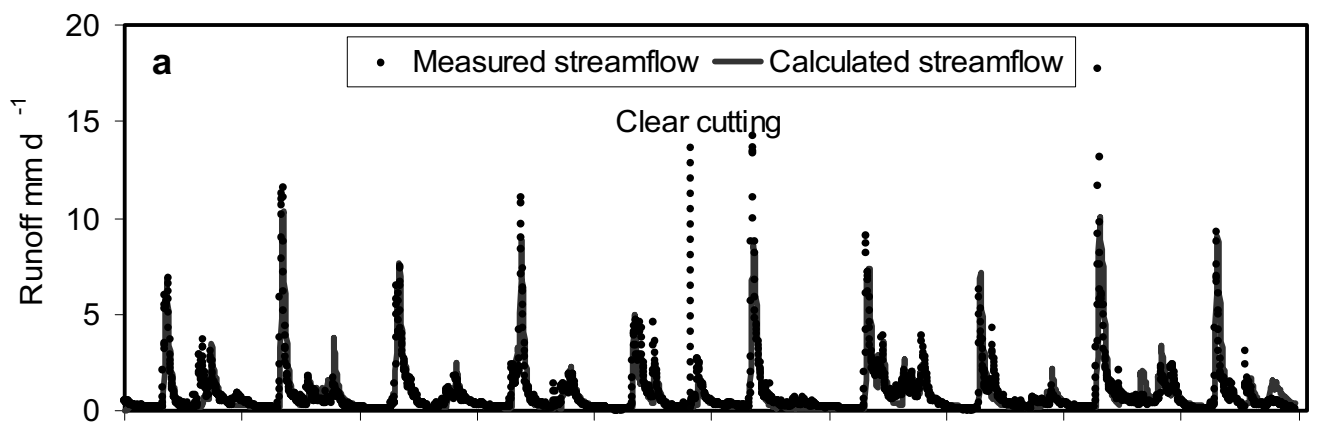

Jan-92 Jan-93 Jan-94 Jan-95 Jan-96 Jan-97 Jan-98 Jan-99 Jan-00 Jan-01 Jan-02

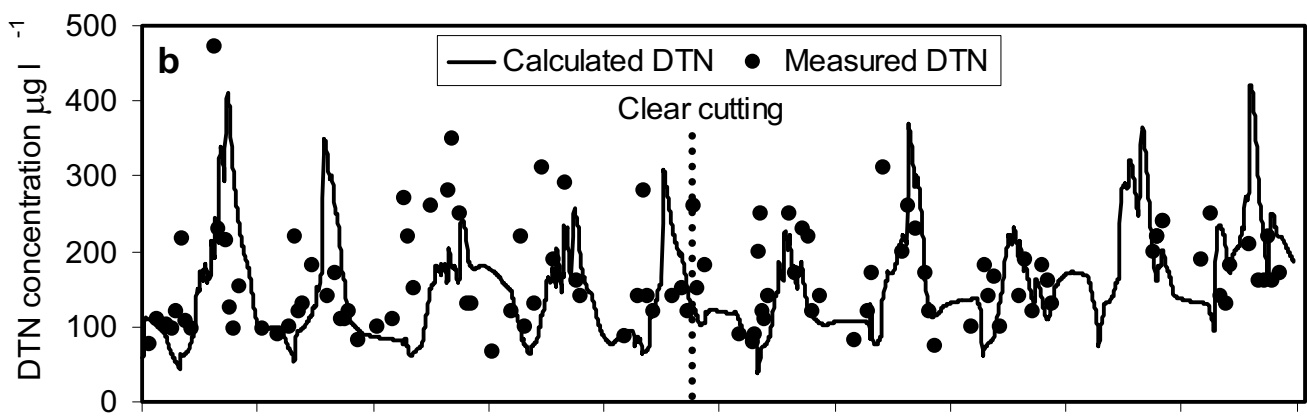

Jan-92 Jan-93 Jan-94 Jan-95 Jan-96 Jan-97 Jan-98 Jan-99 Jan-00 Jan-01 Jan-02

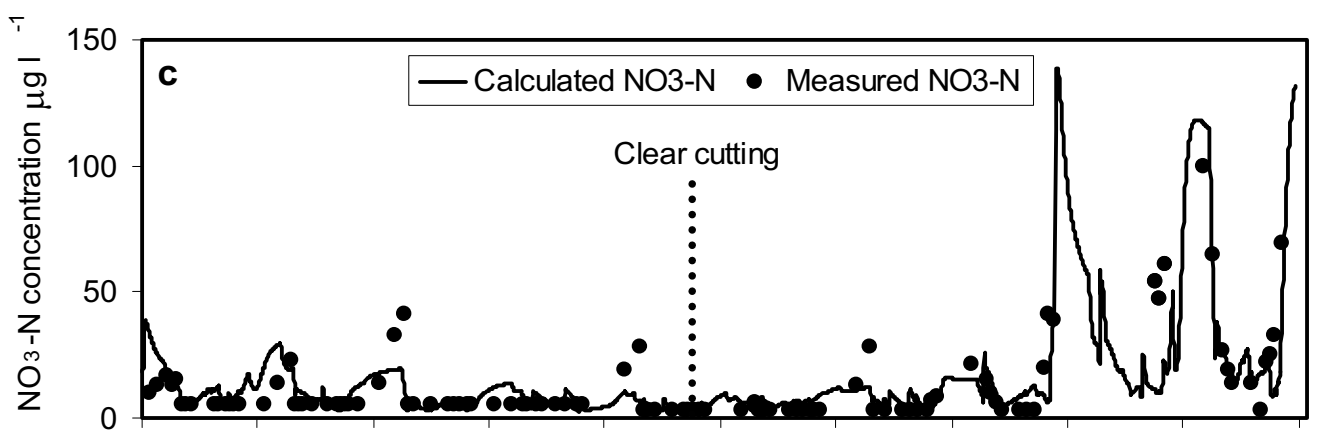

Jan-92 Jan-93 Jan-94 Jan-95 Jan-96 Jan-97 Jan-98 Jan-99 Jan-00 Jan-01 Jan-02

Fig. 4. Stream runoff $\left(\mathrm{mm} \mathrm{d}^{-1}\right)(a)$, measured and simulated concentrations of dissolved total nitrogen (DTN) (b) and nitrate-N (NO $\left.{ }_{3}-N\right)$ (c) in

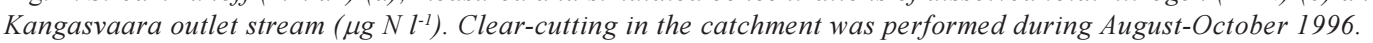

Table 4. Mean of observed stream $\mathrm{N}$ concentrations and exports (monthly values, 1992-2001) and mean error (ME) of modelled results (calculated with Eqn. 3) and Pearson coefficients (r) between the observed and calculated values $(n=110)$.

\begin{tabular}{|c|c|c|c|c|c|c|}
\hline & \multicolumn{3}{|c|}{$\begin{array}{c}\text { Concentration, } \\
\mathrm{mg} \mathrm{l}^{-1}\end{array}$} & \multicolumn{3}{|c|}{$\begin{array}{l}\text { Monthly } N \text { export to } \\
\text { stream, } \mathrm{kg} \mathrm{ha}^{-1}\end{array}$} \\
\hline & Mean & $M E$ & $r$ & Mean & $M E$ & $r$ \\
\hline DTN & 166 & 75 & $0.27 * *$ & 0.043 & 0.025 & $0.63^{* *}$ \\
\hline $\mathrm{NH}_{4}-\mathrm{N}$ & 3 & 3 & -0.10 & 0.001 & 0.001 & $0.32 * *$ \\
\hline $\mathrm{NO}_{3}-\mathrm{N}$ & 13 & 4 & $0.69 * *$ & 0.003 & 0.002 & $0.57 * *$ \\
\hline DON & 151 & 74 & $0.26^{* *}$ & 0.040 & 0.024 & $0.60 * *$ \\
\hline
\end{tabular}

to decrease. According to the simulations, a substantial part of the annual $\mathrm{N}$ export took place during springtime. In the control scenario, $45 \%$ of the annual export of $\mathrm{NO}_{3}-\mathrm{N}$ and $30 \%$ of the annual export of DON occurred between April 15 and May 31, on average. Clear-cutting increased the episodic behaviour of the DON export, $37 \%$ of DON being exported between April 15 and May 31.

\section{NITROGEN FLUXES WITHIN THE CATCHMENT \\ Control scenario}

The mass balance of $\mathrm{N}$ for each soil column along the hillslope was calculated and the results were lumped for each of the three compartments within the catchment (Table 


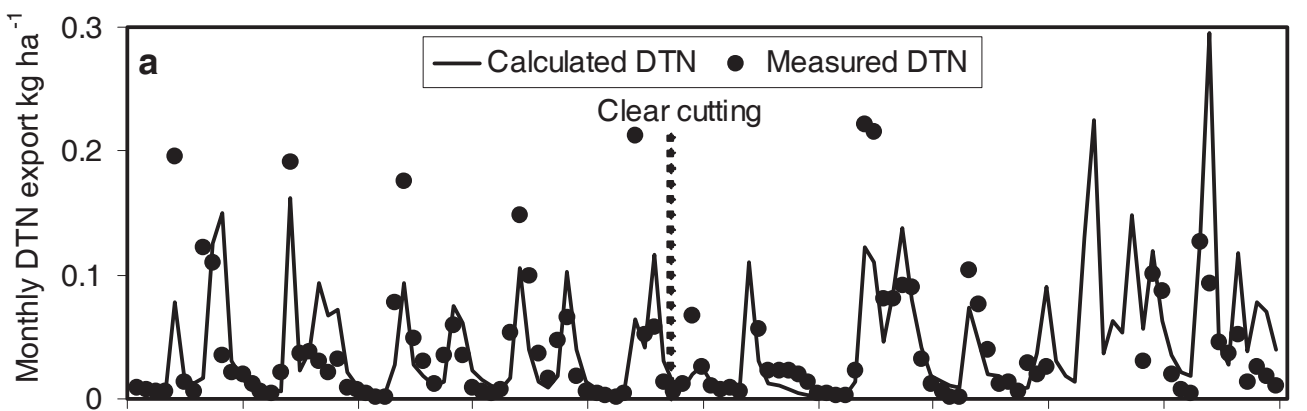

Jan-92 Jan-93 Jan-94 Jan-95 Jan-96 Jan-97 Jan-98 Jan-99 Jan-00 Jan-01 Jan-02

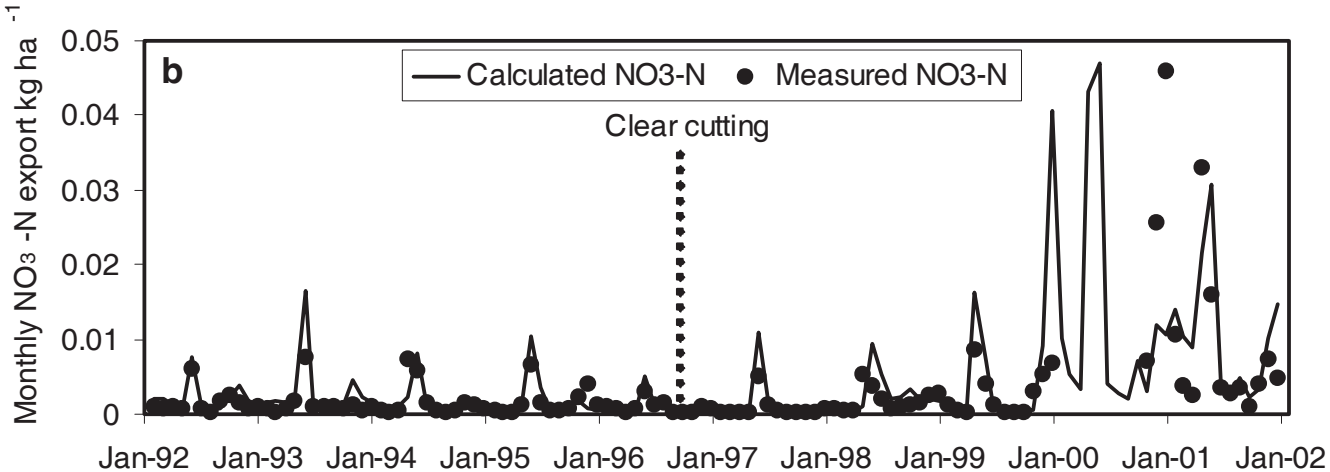

Fig. 5. Observed and simulated exports ( $\mathrm{g} \mathrm{N} \mathrm{ha}^{-1}$ month $\left.^{-1}\right)$ of total dissolved nitrogen (DTN) (a) and nitrate (NO ${ }_{3}^{-N}$ ) (b) in Kangasvaara outlet stream. Clear-cutting in the catchment was performed during August-October 1996.

Table 5. Mean annual $\mathrm{N}$ export $\left(\mathrm{kg} \mathrm{N} \mathrm{ha}^{-1} \mathrm{a}^{-1}\right)$ from the Kangasvaara catchment according to simulations and measurements.

\section{$\mathrm{DTN} \quad \mathrm{NH}_{4}-\mathrm{N} \quad \mathrm{NO}_{3}-\mathrm{N} \quad \mathrm{DON}$}

$\begin{array}{lllll}\begin{array}{l}\text { BEFORE CLEAR-CUTTING } \\ \text { simulated }\end{array} & 0.424 & 0.001 & 0.018 & 0.399 \\ \text { measured } & 0.484 & 0.010 & 0.024 & 0.456 \\ \text { AFTER CLEAR-CUTTING } & & & & \\ \text { simulated } & 0.509 & 0.005 & 0.067 & 0.436 \\ \text { measured } & 0.555 & 0.007 & 0.055 & 0.493\end{array}$

6). The most important influx of $\mathrm{N}$ was the decomposition of organic matter, contributing 51-54 $\mathrm{kg} \mathrm{DTN} \mathrm{ha}^{-1} \mathrm{a}^{-1}$; the deposition input was c. $5 \mathrm{~kg}$ DTN ha $\mathrm{a}^{-1} \mathrm{a}^{-1}$ (Table 6). In the control scenario, the $\mathrm{N}$ influx with the lateral flow of surface and groundwater was less than $0.4 \mathrm{~kg}$ DTN ha-1 $\mathrm{a}^{-1}$, the amount increasing slightly downslope and in convergent locations on the hillslope. Most of the transported DTN was carried by lateral flow of surface waters. Uptake of $\mathrm{N}$ by trees, ground vegetation and immobilisation to microbes were the main outfluxes of $\mathrm{N}$ within the catchment: tree uptake was 20-22 $\mathrm{kg} \mathrm{DTN} \mathrm{ha}^{-1} \mathrm{a}^{-1}$, ground vegetation uptake was $14-18 \mathrm{~kg}$ DTN ha-1 $\mathrm{a}^{-1}$ and microbial immobilisation was $18-19 \mathrm{~kg}^{\mathrm{DTN}} \mathrm{ha}^{-1} \mathrm{a}^{-1}$. The soil $\mathrm{N}$ storage changed little during the simulation period in the control scenario and only a small proportion of $\mathrm{N}$ was exported to the stream (0.42 kg DTN ha-1 $\left.\mathrm{a}^{-}\right)$.

\section{Clear-cutting and buffer zone}

Upon clear-cutting, the $\mathrm{N}$ fluxes changed in the clear-cut area and buffer zone. The amount of dead organic matter increased in the clear-cut area resulting in increased decomposition compared with the control scenario (Table 6 ). The annual mass balances show that decomposition at the end of the simulation period was still higher than before the cutting (Table 7). $\mathrm{N}$ uptake by trees decreased but the microbial immobilisation increased to $71 \mathrm{~kg}$ DTN ha- $\mathrm{a}^{-1}$ in the year following the clear-cutting. However, by the third year (1999) after harvesting the microbial immobilisation of $\mathrm{N}$ decreased to less than $1 \mathrm{~kg} \mathrm{ha}^{-1} \mathrm{a}^{-1}$. Uptake by ground vegetation also was lower in the first two years after clearcutting but, in 1999, it was similar to that before the clearcutting (Table 7). Adsorption storage in soil was the main sink of N from 1998 onwards. After clear-cutting, nitrification increased year by year throughout the simulation period. 
Table 6. Modelled mean annual mass balance of total dissolved nitrogen (DTN, $\mathrm{kg} \mathrm{ha}^{-1} \mathrm{a}^{-1}$ ) for the three modelled compartments under clear-cutting and no cutting scenarios. Calculations are done for the period from October 1996 to December 2001. Compartment 1 is next to the water divide and Compartment 3 is next to the outlet stream. Compartment 1 is mature Norway spruce forest on upland mineral soil, Compartment 2 is similar to Compartment 1 until clear-cutting in October 1996, Compartment 3 is a buffer zone with

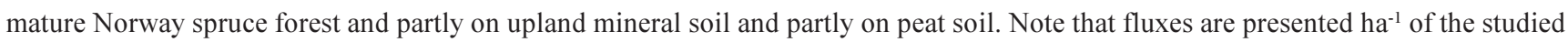
compartment and scaled according to the relative width of the hillslope, thus the outflux from the upslope range does not necessarily equal to influx downslope range in the table. Negative adsorption refers to decrease in adsorption storage.

\begin{tabular}{|c|c|c|c|c|c|c|c|c|c|}
\hline \multirow{3}{*}{$\begin{array}{l}\text { Flux } \\
{\left[\mathrm{kg} \mathrm{N} \mathrm{ha}^{-1} \mathrm{a}^{-1}\right]}\end{array}$} & \multicolumn{3}{|c|}{ Compartment 1} & \multicolumn{3}{|c|}{ Compartment 2} & \multicolumn{3}{|c|}{ Compartment 3} \\
\hline & \multicolumn{3}{|c|}{ SCENARIO } & \multicolumn{3}{|c|}{ SCENARIO } & \multicolumn{3}{|c|}{ SCENARIO } \\
\hline & Cut & Control & Difference & Cut & Control & Difference & Cut & Control & Difference \\
\hline \multicolumn{10}{|l|}{ INFLUXES } \\
\hline Deposition & 5.03 & 5.03 & 0.00 & 6.05 & 5.03 & 1.02 & 5.03 & 5.03 & 0.00 \\
\hline Decomposition & 51.10 & 51.10 & 0.00 & 74.55 & 53.70 & 20.85 & 51.15 & 50.81 & 0.34 \\
\hline Surface water & 0.00 & 0.00 & 0.00 & 0.07 & 0.07 & 0.00 & 15.57 & 0.29 & 15.28 \\
\hline Groundwater & 0.00 & 0.00 & 0.00 & 0.01 & 0.01 & 0.00 & 3.19 & 0.09 & 3.10 \\
\hline \multicolumn{10}{|l|}{ OUTFLUXES } \\
\hline Tree uptake & 20.34 & 20.34 & 0.00 & 2.27 & 21.59 & -19.32 & 28.46 & 21.46 & 7.00 \\
\hline \multicolumn{10}{|l|}{ Ground vegetation } \\
\hline uptake & 16.62 & 16.62 & 0.00 & 17.30 & 17.59 & -0.29 & 18.94 & 14.28 & 4.66 \\
\hline Immobilisation & 19.24 & 19.24 & 0.00 & 19.23 & 19.61 & -0.38 & 19.23 & 17.54 & 1.69 \\
\hline Denitrification & $<0.01$ & $<0.01$ & 0.00 & $<0.01$ & $<0.01$ & 0.00 & $<0.01$ & $<0.01$ & 0.00 \\
\hline \multicolumn{10}{|l|}{$\mathrm{N}_{2} \mathrm{O}-\mathrm{N}$ emission } \\
\hline in nitrification & 0.01 & 0.01 & 0.00 & 0.59 & 0.01 & 0.58 & 0.09 & 0.01 & 0.08 \\
\hline Surface water & $<0.01$ & $<0.01$ & 0.00 & 6.01 & 0.11 & 5.90 & 3.99 & 2.81 & 1.18 \\
\hline Groundwater & $<0.01$ & $<0.01$ & 0.00 & 0.52 & 0.03 & 0.49 & 0.52 & 0.42 & 0.10 \\
\hline \multicolumn{10}{|l|}{$\Delta$ ADSORPTION } \\
\hline storage in soil & -0.14 & -0.14 & 0.00 & 34.51 & -0.14 & 34.65 & 3.70 & -0.33 & 4.03 \\
\hline \multicolumn{10}{|l|}{ OTHER FLUXES } \\
\hline Nitrification & 0.04 & 0.04 & 0.00 & 2.94 & 0.04 & 2.90 & 0.47 & 0.03 & 0.44 \\
\hline
\end{tabular}

Clear-cutting increased the transport of $\mathrm{N}$ with groundwater and surface water flows. The absolute amount of DTN transported from the clear-cut area (Compartment 2) to the buffer zone (Compartment 3) increased by $140 \mathrm{~kg} \mathrm{a}^{-1}$ (Table 8). However, the transport of DTN from the buffer zone to the stream increased by only $10 \mathrm{~kg} \mathrm{a}^{-1}$. According to the simulation, $76 \%$ of the DTN exported from the clearcut area was retained in the buffer zone. Mass balance calculations showed an increase in tree and ground vegetation uptake, microbial immobilisation and soil adsorption storage within the buffer zone (Table 6).

\section{Discussion}

FLUXES EXCLUDED FROM THE MODEL AND THE LIMITATIONS OF THE MODELLING FRAMEWORK

The export of $\mathrm{N}$ from a forested catchment to the outlet stream is affected by many simultaneous interactive processes that are controlled by physical, chemical and biological factors. While the main $\mathrm{N}$ fluxes have been included in the model, explicit calculation of biological $\mathrm{N}$ fixation has been omitted. In boreal forests, biological $\mathrm{N}_{2}$ fixation associated with feather moss (Pleurozium schreberi (Bird.) Mitt) can be $1.5-2 \mathrm{~kg} \mathrm{~N} \mathrm{ha}^{-1} \mathrm{a}^{-1}$ (DaLuca et al., 2002) and the asymbiotic $\mathrm{N}$ fixation $<1 \mathrm{~kg} \mathrm{~N} \mathrm{ha}^{-1} \mathrm{a}^{-1}$ (Hendrickson, 1990). In FEMMA, $N$ fixed by the mosses was included implicitly in the moss litter input but the asymbiotic $\mathrm{N}$ fixation flux was omitted.

The structure of FEMMA sets some limitations to its applications. In representing the catchment as a single hillslope some spatial information is lost. The hydrological model was designed for sites with shallow soils with an impermeable lower boundary (Skaggs, 1980) and so is applicable to the Kangasvaara site. Furthermore, preferential flow in soil macropores, which can be significant in nutrient transport (Kareinen et al., 1998), is not accounted for explicitly in the model. 
Table 7. Annual mass balance of DTN for the clear-cut area before and after harvest.

\begin{tabular}{|c|c|c|c|c|c|c|}
\hline $\begin{array}{l}\text { Flux } \\
{\left[\mathrm{kg} \mathrm{N} \mathrm{ha}{ }^{-1} \mathrm{a}^{-1}\right]}\end{array}$ & Before & 1997 & 1998 & 1999 & 2000 & 2001 \\
\hline \multicolumn{7}{|l|}{ INFLUXES } \\
\hline Deposition & 5.03 & 4.90 & 6.84 & 5.23 & 7.75 & 6.12 \\
\hline Decomposition & 57.57 & 87.82 & 70.80 & 89.66 & 65.31 & 66.53 \\
\hline Surface water & 0.12 & 0.01 & 0.09 & 0.06 & 0.10 & 0.07 \\
\hline Groundwater & 0.02 & 0.06 & 0.01 & 0.01 & 0.01 & 0.01 \\
\hline \multicolumn{7}{|l|}{ OUtFluXes } \\
\hline Tree uptake & 26.46 & 0.08 & 0.25 & 2.29 & 3.46 & 5.47 \\
\hline Ground vegetation uptake & 19.40 & 16.06 & 12.12 & 19.39 & 19.31 & 21.31 \\
\hline Immobilisation & 14.54 & 70.54 & 18.21 & 0.57 & 2.63 & 3.67 \\
\hline Denitrification & $<0.01$ & $<0.01$ & $<0.01$ & $<0.01$ & $<0.01$ & $<0.01$ \\
\hline \multicolumn{7}{|l|}{$\mathrm{N}_{2} \mathrm{O}-\mathrm{N}$ emission } \\
\hline in nitrification & 0.02 & 0.03 & 0.16 & 0.70 & 0.93 & 1.19 \\
\hline Surface water & 0.18 & 0.10 & 1.62 & 3.45 & 14.51 & 10.98 \\
\hline Groundwater & 0.01 & 0.03 & 0.41 & 1.04 & 2.33 & 2.42 \\
\hline $\begin{array}{l}\triangle \text { ADSORPTION } \\
\text { storage in soil }\end{array}$ & 0.10 & 5.94 & 44.91 & 67.53 & 29.99 & 27.67 \\
\hline \multicolumn{7}{|l|}{ OTHER FLUXES } \\
\hline Nitrification & 0.10 & 0.14 & 0.72 & 3.47 & 4.65 & 5.93 \\
\hline
\end{tabular}

Table 8. Mean annual simulated $\mathrm{N}$ transport $\left(\mathrm{kg} \mathrm{DTN} \mathrm{ha}^{-1} \mathrm{a}^{-1}\right)$ from between the three compartments for the period from October 1996 to December 2001. For compartment descriptions, see Table 6.

\begin{tabular}{|c|c|c|c|c|c|c|c|c|c|}
\hline \multirow{2}{*}{$\begin{array}{l}\text { Flux } \\
{\left[\mathrm{kg} \mathrm{N} \mathrm{a}^{-1}\right]} \\
\text { N fraction }\end{array}$} & \multicolumn{3}{|c|}{$\begin{array}{c}\text { Compartment } 1 \rightarrow \text { Compartment } 2 \\
\text { SCENARIO }\end{array}$} & \multicolumn{3}{|c|}{$\begin{array}{c}\text { Compartment } 2 \rightarrow \text { Compartment } 3 \\
\text { SCENARIO }\end{array}$} & \multicolumn{3}{|c|}{$\begin{array}{c}\text { Compartment } 3 \rightarrow \text { Stream } \\
\text { SCENARIO }\end{array}$} \\
\hline & Cut & Control & Difference & Cut & Control & Difference & Cut & Control & Difference \\
\hline DTN & 1.64 & 1.64 & 0.00 & 143.34 & 2.90 & 140.44 & 34.51 & 24.72 & 9.79 \\
\hline $\mathrm{NH}_{4}-\mathrm{N}$ & 0.06 & 0.06 & 0.00 & 105.54 & 0.15 & 105.39 & 0.18 & 0.05 & 0.13 \\
\hline $\mathrm{NO}_{3}-\mathrm{N}$ & 0.92 & 0.92 & 0.00 & 20.72 & 1.62 & 19.10 & 4.50 & 1.30 & 3.20 \\
\hline DON & 0.66 & 0.66 & 0.00 & 17.08 & 1.13 & 15.95 & 29.82 & 23.38 & 6.44 \\
\hline
\end{tabular}

\section{RESULTS IN THE CONTEXT OF PREVIOUS EXPERIMENTS}

The model has been applied to a catchment in which the forest growth is $\mathrm{N}$-limited and deposition low; $\mathrm{N}$ is, thus, tightly cycled and export to the stream is at the lower end of the range reported in other studies (Lepistö,1995; Moldan and Wright, 1998b; Ahtiainen and Huttunen, 1999; Mattsson et al., 2003; Åström et al., 2003; Akselsson et al., 2004).

One of the main goals of this study was to simulate $\mathrm{N}$ fluxes down a representative hillslope that extended from the water divide to the stream. In Sweden, Jacks and Norrström (2004) have studied N transport along transects from both a clear-cut area on upland mineral soil through a riparian buffer zone to a stream as well as from a pristine boreal coniferous forest draining to a stream. The clear-cut area in their study was $73 \%$ of the catchment and the buffer zone $9 \%$ (corresponding values in the present study catchment were $35 \%$ and $14 \%$ ). They estimated the $\mathrm{N}$ export using runoff data and $\mathrm{N}$ concentrations in water collected with piezometers installed along the transects. The $\mathrm{N}$ export from the clear-cut hillslope to the buffer zone was $41 \mathrm{~kg} \mathrm{~N}$ $\mathrm{ha}^{-1} \mathrm{a}^{-1}$ and from the uncut hillslope $1.6 \mathrm{~kg} \mathrm{~N} \mathrm{ha}^{-1} \mathrm{a}^{-1}$ indicating that clear-cutting had caused a 26 -fold increase in $\mathrm{N}$ exports to the buffer zone. According to their calculations, $73 \%$ of the $\mathrm{N}$ exported from the clear-cut area 
was retained in the buffer zone during the one-year study period. In the present Kangasvaara simulations, the mean annual outflux from the clear-cut area was $6.48 \mathrm{~kg} \mathrm{~N} \mathrm{ha}^{-1} \mathrm{a}^{-1}$, while the outflux from the control scenario was $0.21 \mathrm{~kg} \mathrm{~N}$ $\mathrm{ha}^{-1} \mathrm{a}^{-1}$ (see Table 6). Thus, clear-cutting had increased the $\mathrm{N}$ export to the buffer zone 31 -fold and some $76 \%$ of the DTN was retained in the buffer zone (Table 8). Considering the differences between the sites, the uncertainties in the modelling and measurements, the results of these two studies are remarkably similar.

According to the simulation, the release of $\mathrm{N}$ associated with decomposition was the main source of $\mathrm{N}$ into the soilwater system. Experimental quantification of $\mathrm{N}$ release from organic material is rather problematic because several processes affect the net $\mathrm{N}$ release, including mineralisation, nitrification, denitrification, microbe assimilation and uptake (Persson et al., 2000). Comparison of experimental $\mathrm{N}$ release studies is not always straightforward because measurement methods often differ (Staaf and Berg, 1982; Berg, 1988; Hasegava and Takeda, 1996; Devito et al., 1999; Andersson et al., 2002; Bengtsson et al., 2003; Vestgarden et al., 2003). The ROMULN model was calibrated against litterbag results from the catchment studied using logging residues (Palviainen et al., 2004). Critical concentration parameters (Table 2) in the model were adjusted to replicate the measured $\mathrm{N}$ contents in foliar, branch and fine root logging residues for three consecutive years after the clear-cutting. The changes made to the ROMUL model related mainly to the $\mathrm{N}$ dynamics of the $\mathrm{F}$ pool, in which fractions of an organic matter cohort stay for a maximum of a few years; the dynamics of the old organic matter in $\mathrm{H}$ succession phase, were not changed.

In the present simulations, the mean annual net $\mathrm{N}$ release (calculated as decomposition - immobilisation) was 31-34 $\mathrm{kg} \mathrm{N} \mathrm{ha} \mathrm{a}^{-1} \mathrm{a}^{-1}$ in the control scenario and $17 \mathrm{~kg} \mathrm{~N} \mathrm{ha}^{-1} \mathrm{a}^{-1}$ during the first year after clear-cutting (Tables 6 and 7). The maximum simulated net annual mineralisation, $89 \mathrm{~kg}$ $\mathrm{N} \mathrm{ha}^{-1} \mathrm{a}^{-1}$, occurred three years after clear-cutting. These results fall within the range reported for Scandinavian forest soils, $0-110 \mathrm{~kg} \mathrm{~N} \mathrm{ha}^{-1} \mathrm{a}^{-1}$ (Persson and Wirén, 1995; Persson et al., 2000; Kjønaas et al., 1998; Andersson et al., 2002).

Kjønaas et al. (1998) studied the effects of $\mathrm{N}$ addition on $\mathrm{N}$ cycling in three Swedish catchments of mature Norway spruce stands; the addition of $\mathrm{N}$ increased the assimilation by soil and microbes to $83 \mathrm{~kg} \mathrm{~N} \mathrm{ha}{ }^{-1} \mathrm{a}^{-1}$ and net mineralisation to $75.5 \mathrm{~kg} \mathrm{~N} \mathrm{ha}^{-1} \mathrm{a}^{-1}$. In the present study, clear-cutting increased especially decomposition, immobilisation and soil storage; during the first year after the clear-cutting, $71 \mathrm{~kg} \mathrm{~N} \mathrm{ha}^{-1} \mathrm{a}^{-1}$ was assimilated by the microbe populations associated with the logging residues (Table 7), in agreement with the results of Kjønaas et al. (1998).
For Scandinavian forest soils, reported nitrification rates vary from $0-76 \mathrm{~kg} \mathrm{~N} \mathrm{ha}^{-1} \mathrm{a}^{-1}$ (Persson and Wiren, 1995; Kjønaas et al., 1998; Persson et al., 2000; Andersson et al., 2002; Vestgarden et al., 2003). In pristine conditions, the rate of nitrification is rather low. In the present study, nitrification under pristine conditions was $0.03-0.04 \mathrm{~kg} \mathrm{~N}$ $\mathrm{ha}^{-1} \mathrm{a}^{-1}$; after clear-cutting it increased to a maximum of 5.93 $\mathrm{kg} \mathrm{N} \mathrm{ha}^{-1} \mathrm{a}^{-1}$ in 2001 (Tables 6 and 7). However, these values should be viewed with caution, because nitrification parameter (nrate) was calibrated against measured nitrate concentrations in the stream. Soil $\mathrm{pH}$ in the topmost layer was 4.0, the critical value at which nitrification becomes low (Persson and Wirén, 1995). However, clear-cutting increases soil $\mathrm{pH}$ and available $\mathrm{NH}_{4}-\mathrm{N}$ such that nitrification may be initiated (Smolander et al., 1998; Paavolainen and Smolander, 1998).

Nitrification can lead to the production of gaseous $\mathrm{N}_{2} \mathrm{O}-\mathrm{N}$, although this is usually a minor source of $\mathrm{N}_{2} \mathrm{O}-\mathrm{N}$ from forest soils compared to denitrification (Ambus, 1998). No values were found in the literature for $\mathrm{N}_{2} \mathrm{O}-\mathrm{N}$ production from clear-cut areas but, according to the simulations, the flux of $\mathrm{N}_{2} \mathrm{O}-\mathrm{N}$ from the clear-cut area was $0.59 \mathrm{~kg} \mathrm{~N}$ $\mathrm{ha}^{-1} \mathrm{a}^{-1}$ (Table 6). For pristine peatlands and unfertilised coniferous forests on upland soils, $\mathrm{N}_{2} \mathrm{O}-\mathrm{N}$ emissions are very low, a few tens of grams $\mathrm{N} \mathrm{ha}^{-1} \mathrm{a}^{-1}$ (Matson et al., 1992; Martikainen et al., 1993). $\mathrm{N}_{2} \mathrm{O}-\mathrm{N}$ emissions from drained forested peatlands are higher $\left(1.2-5.2 \mathrm{~kg} \mathrm{~N} \mathrm{ha}^{-1} \mathrm{a}^{-1}\right)$ because drainage enhances the decomposition of peat and increases the amount of dissolved $\mathrm{NH}_{4}-\mathrm{N}$ in the soil (Martikainen et al., 1993; Regina et al., 1998a; Regina et al., 1998b; Maljanen et al., 2003). Fertilisation or deposition also increase the amounts of dissolved $\mathrm{NH}_{4}-\mathrm{N}$ in the soil, thereby enhancing the gaseous $\mathrm{N}$ emissions. However, effects on well drained mineral soils are smaller than on drained peatlands (Klemedtsson et al., 1997). That could indicate that gaseous $\mathrm{N}$ emissions would increase after clear-cutting but not to the level at drained forested peatlands. $\mathrm{N}_{2} \mathrm{O}-\mathrm{N}$ fluxes have been estimated simply as a linear function of nitrification although they may be affected by many factors, such as water content and temperature, freezing and thawing cycles and soil $\mathrm{pH}$. The factors controlling gaseous fluxes at low temperature are still poorly known (Teepe et al., 2000; Öquist et al., 2004).

\section{CHALLENGES FOR THE MODEL AND FUTURE} PROSPECTS

The FEMMA model succeeded in simulating stream runoff and the annual export and seasonal dynamics of $\mathrm{N}$ concentration in the stream water. As with many models working at the daily time-step, the reproduction of responses 
to individual events is not very good. Moreover, a 'correct' $\mathrm{N}$ export may reflect a combination of incorrectly modelled $\mathrm{N}$ fluxes within the catchment. Simulated N fluxes within the catchment were high compared with $\mathrm{N}$ export in stream water. The cycling of $\mathrm{N}$ between litter, microbes, soil and vegetation was almost closed, the measured annual export of DTN was only about $1 \%$ of the calculated annual release of $\mathrm{N}$ by decomposition and the exports of $\mathrm{NO}_{3}-\mathrm{N}$ and $\mathrm{NH}_{4}-\mathrm{N}$ into the stream were respectively only 1.6 and $0.8 \%$ of the measured deposition loads. The closed nature of the $\mathrm{N}$ cycle makes the experimental and modelling work challenging because errors in mass balance components can result in a big relative response to the observed and modelled output.

The approach used in FEMMA fills the gap between pointscale and large-scale models by simulating fluxes of water and $\mathrm{N}$ down-slope through different land-use types and including DON. Exploiting these new properties enable adjusting forest management practices inside the catchment in a way that minimises the $\mathrm{N}$ export. Some of these studies could be done with fully distributed three-dimensional models that have been developed (MIKE SHE, Boegh et al., 2004), but applications to forested environments are rare. Previous modelling of $\mathrm{N}$ leaching to streams has concentrated on inorganic forms but FEMMA also simulates DON fluxes.

FEMMA should be further developed towards more generic applicability of the model. This requires testing the model against independent datasets from paired catchment studies conducted under different deposition, land-use and forest and soil types. Inclusion of phosphorous and acidifying ions into the model would widen the user group of the model. On the other hand, experimental element transport data along the water pathway on the hillslope is still required to test the validity of the results within the catchment.

\section{Conclusions}

The key results in the present work were:

- A new model enabling the down-slope routing of water and $\mathrm{N}$ through different land-use types and the inclusion of DON.

- The model simulation showed that the most important sinks of $\mathrm{N}$ after the clear-cutting were immobilisation by the soil microbes, uptake by ground vegetation and sorption to soil.

- Simulations suggested also that the buffer zone retained a substantial part of the $\mathrm{N}$ flux before reaching the outlet stream.
Currently, FEMMA can be applied only to experimental sites having data for calibration and so cannot yet be used as a decision support system in operational environment management. However, such applications identify which processes are particularly important in affecting $\mathrm{N}$ export and which combinations of forest management options, site type, soil type, catchment dimensions and climate risk high $\mathrm{N}$ loading to streams. This information can then be applied in prescribing practical forest management operations.

\section{Acknowledgements}

The FEMMA research project has been partly funded by the Academy of Finland (No. 52740). On-site hydrometeorological data at Kangasvaara were collected in the VALU project and additional meteorological data were kindly provided by the Finnish Meteorological Institute. Encouragement from Professor Pertti Vakkilainen, Doctors Keijo Nenonen, Pekka Hänninen, Sari Penttinen, Sirpa Piirainen and Michael Starr is greatly acknowledged.

\section{References}

Ahonen, J., Rankinen, K., Holmberg, M., Syri, S. and Forsius, M., 1998. Application of the SMART2 model to a forested catchment in Finland: comparison to the SMART model and effects of emission reduction scenarios. Bor. Environ. Res., 3, 221-233.

Ahtiainen, M. and Huttunen, P., 1999. Long-term effects of forestry managements on water quality and loading in brooks. Bor. Environ. Res., 4, 101-114.

Akselsson, C., Westling, O. and Örlander, G., 2004. Regional mapping of nitrogen leaching from clearcuts in southern Sweden. Forest Ecol. Manage. (in press)

Andersson, P., Berggren, D. and Nilsson, I., 2002. Indices for nitrogen status and nitrate leaching from Norway spruce (Picea abies (L.) Karst.) stands in Sweden. Forest Ecol. Manage., 157, 39-53.

Ambus, P., 1998. Nitrous oxide production by denitrification and nitrification in temperate forest, grassland and agricultural soils. Eur. J. Soil Sci., 49, 495-502.

Arheimer, B. and Wittgren, H.B., 2002. Modelling nitrogen removal in potential wetlands at the catchment scale. Ecol. Eng., 19, 63-80.

Åström, M., Aaltonen, E.-K. and Koivusaari, J., 2003. Impact of forest ditching on nutrient loadings of a small stream - a paired catchment study in Kronby, W. Finland. Sci. Total Envir., 297, 127-140.

Bååth, E., Frostegård, A., Pennanen, T. and Frize, H., 1995. Microbial community structure and $\mathrm{pH}$ response in relation to soil organic matter quality in wood-ash fertilizes, clear-cut or burned coniferous forest soils. Soil Biol. Biochem., 27, 229240.

Bauhus, J., 1996. C and N mineralization in an acid forest soil along a gap-stand gradient. Soil Biol. Biochem., 28, 923-932.

Bäumler, R. and Zech, W., 1999. Effects of forest thinning on streamwater chemistry on two forest watersheds in the Bavarian Alps. Forest Ecol. Manage., 116, 119-128. 
Bengtsson, G., Bengtson, P. and Månsson, F., 2003. Gross nitrogen mineralisation-, immobilisation-, and nitrification rates as a function of soil $\mathrm{C} / \mathrm{N}$ ratio and microbial activity. Soil Biol. Biochem., 35, 143-154.

Berg, B., 1988. Dynamics of nitrogen $\left({ }^{15} \mathrm{~N}\right)$ in decomposing Scots pine (Pinus sylvestris) needle litter. Long-term decomposition in a Scots pine forest. VI. Can. J. Bot., 66, 1539-1546.

Berg, B. and Söderström, B., 1979. Fungal biomass and nitrogen in decomposing Scots pine needle litter. Soil Biol. Biochem., 11, 339-341.

Berg, B. and Staaf, H., 1981. Leaching, accumulation and release of nitrogen in decomposing forest litter. In: Terrestrial Nitrogen Cycles, F.E. Clarck and T. Rosswall, (Eds.). Ecol. Bull. (Stockholm), 33, 163-178.

Berg, B. and Theander, O., 1984. Dynamics of some nitrogen fractions in decomposing Scots pine needle litter. Pedobiologia, 27, 261-267.

Boegh, E., Thorsen, M., Butts, M.B., Hansen, S., Christiansen, J.S., Abrahamsen, P., Hasager, C.B., Jensen, N.O., van der Keur, P., Refsgaard, J.C., Schelde, K., Soegaard, H., Thomsen, A., 2004. Incorporating remote sensing data in physically based distributed agro-hydrological modeling. J. Hydrol. 287, 279-299.

Bredemeier, M., Blanck, K., Xu, Y.-J., Tietema, A., Boxman, A.W., Emmet, B., Moldan, F., Gundersen, P., Schleppi, P. and Wright, R.F., 1998. Input-output budgets at the NITREX sites. Forest Ecol. Manage., 101, 57-64.

Buttle, J.M., Creed, I.F. and Pomeroy, J.W., 2000. Advances in Canadian forest hydrology, 1995-1998. Hydrol. Process., 14, $1551-1578$.

Cajander, A.K., 1949. Forest types and their significance. Acta For. Fenn., 56, 1-72.

Calder, I.R., 1990. Evaporation in the uplands. Wiley, Chichester, UK.166pp.

Chertov, O.G. and Komarov, A.S., 1997. SOMM: A model of soil organic matter dynamics. Ecol. Model., 94, 177-189.

Chertov, O.G., Komarov, A.S., Nadporozhskaya, M., Bykhovets, S.S. and Zudin, S.L., 2001. ROMUL - a model of forest soil organic matter dynamics as a substantial tool for forest ecosystem modelling. Ecol. Model., 138, 289-308.

DaLuca, T.H., Zackrisson, O., Nilsson, M.-C. and Sellstedt, A., 2002. Quantifying nitrogen-fixation in feather moss carpets of boreal forests. Nature, 419, 917-920.

Devito, K.J., Westbrook, C.J. and Schiff, S.L., 1999. Nitrogen mineralization and nitrification in upland and peatland forest soils in two Canadian Shield catchments. Can. J. Forest Res., 29, 1793-1804.

Eckersten, H. and Beier, C., 1998. Comparison of $\mathrm{N}$ and $\mathrm{C}$ dynamics in two Norway spruce stands using a process oriented simulation model. Environ. Pollut., 102, 395-401.

Eckersten, H., Gärdenas, A. and Jansson, P.-E., 1995. Modelling seasonal nitrogen, carbon, water and heat dynamics of the Solling spruce stand. Ecol. Model., 83, 119-129.

Emmet, B.A., Andersson, J.M. and Hornung, M., 1991. Nitrogen sinks following two intensities of harvesting in Sitka spruce forest (N. Wales) and the effect on the establishment of the next crop. Forest Ecol. Manage., 41, 81-93.

Fahey, T.J., Hill, M.O., Stevens, P.A., Hornung, M. and Rowland, P., 1991. Nutrient accumulation in vegetation following conventional and whole-tree harvest of Sitka spruce plantations in North Wales. Forestry, 64, 271-288.

FAO, 1988. FAO/UNESCO Soil map of the World, Revised Legend. World Resources report 60, Rome, Reprinted as Technical Paper 20. ISRIC, Wageningen, The Netherlands, 1989.
Finér, L., Ahtiainen, M., Mannerkoski, H., Möttönen, V., Piirainen, S., Seuna, P. and Starr, M., 1997. Effects of harvesting and scarification on water and nutrient fluxes. A description of catchment and methods, and results from the pre-treatment calibration period. Finnish Forest Research Institute, Research papers, 648. 38pp.

Finér, L., Mannerkoski, M., Piirainen, S. and Starr, M., 2003. Carbon and nitrogen pools in a old-growth, Norway spruce mixed forest in eastern Finland and changes associated with clear-cutting. Forest Ecol. Manage.,174, 51-63.

Francos, A., Bidoglio, G., Galbiati, L., Bouraoui, F., Elorza, F.J., Rekokainen, S., Manni, K. and Granlund, K., 2001. Hydrological and water quality modelling in a medium-sized coastal basin. Phys. Chem. Earth, 26, 47-52.

Gebauer, G., Zeller, B., Schmidt, G., May, C., Buchmann, N., Colin-Belgrand, M., Dambrine, E., Martin, F., Schulze, E.-D. and Bottner, P., 2000. The fate of ${ }^{15} \mathrm{~N}$-labelled nitrogen inputs to coniferous and broadleaf forests. In: Carbon and nitrogen cycling in European forest ecosystems, E.-D. Schulze, (Ed.). Springer, Berlin, Germany. 144-170.

Glinski, J. and Stepniewski, W. 1985. Soil aeration and its role for plants. CRC Press, Inc., Boca Raton, FL., USA. 229pp.

Gourley, C.J.P., Allan, D.L. and Russelle, M.P., 1994. Plant nutrient efficiency: a comparison of definitions and suggested improvement. Plant Soil, 158, 29-37.

Grip, H. 1982. Water chemistry and runoff in forest streams at Kloten. Uppsala Universitet Naturgeografiska Institutionen UNGI 58. 80pp.

Hannam, K.D. and Prescott, C.E., 2003. Soluble organic nitrogen in forests and adjacent clearcuts in British Columbia. Can. J. Forest Res., 33, 1709-1718.

Hasegava, M. and Takeda, H., 1996. Carbon and nutrient dynamics in decomposing pine needle litter in relation to fungal and faunal abundances. Pedobiologia, 40, 171-184.

Hendrickson, O.Q., 1990. Asymbiotic nitrogen fixation and soil metabolism in three Ontario forests. Soil Biol. Biochem., 22, 967-971.

Houston, A.P.C., Visser, S. and Lautenschlager, R.A., 1998. Microbial processes and fungal community structure in soils from clear-cut and unharvested areas of two mixedwood forests. Can. J. Bot., 76, 630-640.

Jacks, G. and Norrström, A.C., 2004. Hydrochemistry and hydrology of forest riparian wetlands. Forest Ecol. Manage., 196, 187-197.

Jansson, P.-E. and Karlberg, L., 2001. Coupled heat and mass transfer model for soil-plant-atmosphere systems. Royal Institute of Technology, Dept of Civil and Environmental Engineering, Stockholm, Sweden. 321pp.

Jenkins, A., Ferrier, R.C. and Cosby, B.J., 1997. A dynamic model for assessing the impact of coupled sulphur and nitrogen deposition scenarios on surface water acidification. J. Hydrol., 197, 111-127.

Jenkins, A., Ferrier, R.C. and Helliwell, R.C., 2001. Modelling nitrogen dynamics at Lochnagar, N.E. Scotland. Hydrol. Earth Syst. Sci., 5, 519-527.

Kämäri, J., Rankinen, K., Finér, L., Piirainen, S. and Posch, M., 1998. Modelling response of soil and runoff chemistry to forest harvesting in a low deposition area (Kangasvaara, Eastern Finland). Hydrol. Earth Syst. Sci., 2, 485-495.

Kareinen, T., Nissinen, A. and Ilvesniemi, H., 1998. Analysis of forest soil chemistry and hydrology with a dynamic model ACIDIC. Acta For. Fenn., 262, 42.

Karvonen, T., Koivusalo, H., Jauhiainen, M., Palko, J. and Weppling, K., 1999. A hydrological model for predicting runoff from different land use areas. J. Hydrol., 217, 253-265. 
Kellomäki, S. and Väisänen, H., 1997. Modelling the dynamics of the forest ecosystem for climate change studies in the boreal conditions. Ecol. Model., 97, 121-140.

Kielland, K., 1994. Amino acid uptake by arctic plants. Ecology, 75, 2373-2383.

Kirschbaum, M.U.F. and Paul, K.I., 2002. Modelling C and N dynamics in forest soils with a modified version of the CENTURY model. Soil Biol. Biochem., 34, 341-354.

Kjønaas, O.J., Stuanes, A.O. and Huse, M., 1998. Effects of weekly nitrogen additions on $\mathrm{N}$ cycling in a coniferous forest catchment, Gårdsjön, Sweden. Forest Ecol. Manage., 101, 227-249.

Kjønaas, O.J. and Wright, R.F., 1998. Nitrogen leaching from $\mathrm{N}$ limited forest ecosystems: the MERLIN model applied to Gårdsjön, Sweden. Hydrol. Earth Syst. Sci., 2, 415-429.

Klemedtsson, L., Kasimir-Klemedtsson, Å., Moldan, F. and Weslien, P., 1997. Nitrous oxide emission from Swedish forest soils in relation to liming and simulated increased N-deposition. Biol. Fert. Soils, 25, 290-295.

Klinka, K., Green, R.N., Trowbridge, R.L. and Lowe, L.E., 1981. Taxonomic classification of humus forms in ecosystems of British Columbia. First Approximation. Ministry of Forests. Province of British Columbia, Canada. 54pp.

Koivusalo, H. and Kokkonen, T., 2002. Snow processes in a forest clearing and in a coniferous forest. J. Hydrol., 262, 145-162.

Koivusalo, H., Heikinheimo, M. and Karvonen, T., 2001. Test of a simple two-layer parametrisation to simulate the energy balance and temperature of a snowpack. Theor. Appl. Climatol., 70, 65-79.

Koivusalo, H., Kokkonen, T., Laurén, A., Ahtiainen, M., Karvonen, T., Mannerkoski, H. Penttinen, S., Seuna, P., Starr, M. and Finér, L., 2005. Parameterisation and application of a hillslope hydrological model to assess impacts of a forest clear-cutting on runoff generation. Accepted by Environ. Model. Software.

Koivusalo, H. and Kokkonen, T., 2003. Modelling runoff generation in a forested catchment in southern Finland. Hydrol. Process., 17, 313-328.

Kokkonen, T., Koivusalo, H. and Karvonen, T. 2001. A semidistributed approach to rainfall-runoff modelling - a case study in a snow affected catchment. Environ. Model Software, 16, 481-493.

Krám, P., Laudon, H., Bishop, K., Rapp, L. and Hruška, J., 2001. MAGIC modelling of long-term lake water and soil chemistry at Abborrträsket, Northern Sweden. Water Air Soil Pollut., 130, $1301-1306$

Krysanova, V., Müller-Wohlfeil, D.-I. and Becker, A., 1998. Development and test of a spatially distributed hydrological/ water quality model for mesoscale watersheds. Ecol. Model., 106, 261-289.

Kubin, E., 1995. The effect of clear cutting, waste wood collecting and site preparation on the nutrient leaching to groundwater. In: Nutrient uptake and cycling in forest ecosystems. L.O. Nilsson and R.F. Hüttl, (Eds.). Kluwer, The Netherlands. 661670

Lamontagne, S., Schiff, S. and Elgood, J., 2000. Recovery of 15Nlabelled nitrate applied to a small upland boreal forest catchment. Can. J. Forest Res., 30, 1165-1177.

Langusch, J.-J. and Matzner, E., 2002. N fluxes in two nitrogen saturated forested catchments in Germany: dynamics and modelling with INCA. Hydrol. Earth Syst. Sci., 6, 383-394.

Lepistö, A., 1995. Increased leaching of nitrate at two forested catchments in Finland over a period of 25 years. J. Hydrol., 171, 103-123.

Lepistö, A., Andersson, L., Arheimer, B. and Sundblad, K., 1995. Influence of catchment characteristics, forestry activities and deposition on nitrogen export from small forested catchments. Water Air Soil Poll., 84, 81-201.
Li, C., Frolking, S. and Frolking, T., 1992. A model of nitrous oxide evolution from soil driven by rainfall events: 1 . Model structure and sensitivity. J. Geophys. Res., 97, 9759-9776.

Likens, G.E., Bormann, F.H., Johnson, N.M., Fisher, D.W. and Pierce, R.S., 1970. Effects of forest cutting and herbicide treatment on nutrient budgets in the Hubbard Brook watershedecosystem. Ecol. Monogr., 40, 23-47.

Lindo, Z and Visser, S., 2003. Microbial biomass, nitrogen and phosphorous mineralization, and mesofauna in boreal conifer and deciduous forest floors following partial and clear-cut harvesting. Can. J. Forest Res., 33, 1610-1620.

Lundell,Y. and Albrektson, A., 1997. Downslope effects of clearcutting in Sweden on diameter increment of Picea abies and Pinus sylvestris. Scand. J. For. Res., 12, 241-247.

Maljanen, M., Liikanen, A., Silvola, J. and Martikainen, P.J., 2003. Nitrous oxide emissions from boreal organic soil under different land-use. Soil Biol. Biochem., 35, 689-700.

Mälkönen, E., 1974. Annual primary production and nutrient cycle in some Scots pine stands. Commun. Inst. For. Fenn., 84.5, 187.

Martikainen, P.J., 1985. Nitrous oxide emission associated with autotrophic ammonium oxidation in acid coniferous soil. Appl. Environ. Microb., 50, 1519-1525.

Martikainen, P.J., Nykänen, H., Crill, P. and Silvola, J., 1993. Effect of a lowered water table on nitrous oxide from northern peatlands. Nature, 366, 51-53.

Matson, P.A., Gower, S.T., Volkman, C., Billow, C. and Grier, C.C., 1992. Soil nitrogen cycling and nitrous oxide flux in a Rocky Mountain Douglas-fir forest: effects of fertilization, irrigation and carbon addition. Biogeochemistry, 18, 101-117.

Mattsson, T., Finér, L., Kortelainen, P. and Sallantaus, T., 2003. Brook water quality and background leaching from unmanaged forested catchments in Finland. Water Air Soil Pollut., 147, 275297.

Moldan, F. and Wright, R.F., 1998a. Changes in runoff chemistry after five years of $\mathrm{N}$ addition to a forested cathchent at Gårdsjön, Sweden. Forest Ecol. Manage., 101, 187-197.

Moldan, F. and Wright, R.F., 1998b. Episodic behaviour of nitrate in runoff during six years of nitrogen addition to the NITREX catchment at Gårdsjön, Sweden. Environ. Pollut., 102, 439444

Molina, J.A.E., Clapp, C.E., Shaffer, M.J., Chichester, F.W. and Larson, W.E., 1983. NCSOIL, a model of nitrogen and carbon transformations in soil: description, calibration and behaviour. Soil Sci. Soc. Amer. J., 47, 85-91.

Mou, P., Fahey, T.J. and Hughes, J.W., 1993. Effects of soil disturbance on vegetation recovery and nutrient accumulation following whole-tree harvest of a northern hardwood ecosystem. J. Appl. Ecol., 30, 661-675.

Näsholm, T., Ekblad, A., Nordin, A., Giesler, R., Högberg, M. and Högberg, P., 1998. Boreal forest plants take up organic nitrogen. Nature, 392, 914-916.

Nykvist, N., 1971. The effect of clear felling on the distribution of biomass and nutrients. Ecol. Bull., 14, 166-178.

Nykvist, N., 1997. Changes in species occurrence and phytomass after clearfelling, prescribed burning and slash removal in two Swedish spruce forests. Studia Forestalia Suecica, 201. 33pp.

Olsson, B.A., Staaf, H., Lundkvist, H., Bengtsson, J. and Rosén, K., 1996. Carbon and nitrogen in coniferous forest soils after clear-felling and harvests of different intensity. Forest Ecol. Manage., 82, 19-32.

Öquist, M.G., Nilsson, M., Sörensson, F., Kasimir-Klemedtsson, Å., Persson, T., Weslien, P. and Klemedtsson, L., 2004. Nitous oxide production in forest soil at low temperatures - processes and environmental controls. FEMS Microbiol. Ecol., 49, 371378. 
Paavolainen, L. and Smolander, A., 1998. Nitrification and denitrification in soil from a clear-cut Norway Spruce (Picea abies) stand. Soil Biol. Biochem., 30, 775-781.

Päivänen, J., 1982. The effect of cutting and fertilization on the hydrology of an old forest drainage area (in Finnish with an English summary), Folia Forestalia 516, Institutum Forestale Fenniae, Helsinki, Finland. 19 pp.

Palviainen, M., Finér, L., Kurka, A.-M., Mannerkoski, M., Piirainen, S. and Starr, M., 2004. Decomposition and nutrient release from logging residues after clear-cutting of mixed boreal forest. Plant Soil, 263, 53-67.

Palviainen, M., Finér, L., Piirainen, S. and Starr, M., 2005. Changes in above- and below-ground biomass and nutrient pools of ground vegetation after clear- cutting of a mixed boreal forest. Plant Soil, in press

Pardo, L.H., Hemond, H.F., Montoya, J.P., Fahey, T.J. and Siccama, T.G., 2002. Response of the natural abundance of ${ }^{15} \mathrm{~N}$ in forest soils and foliage to high nitrate loss following clearcutting. Can. J. Forest Res., 32, 1126-1136.

Persson, T. and Wirén, A., 1995. Nitrogen mineralization and potential nitrification at different depths in acid forest soils. Plant Soil, 168-169, 55-65.

Persson, T., Rudebeck, A., Jussy, J.H., Colin-Belgrand, M., Priemé, A., Dambrine, E., Karlsson, P.S. and Sjöberg, R.M., 2000. Nitrogen turnover - mineralization, nitrification and denitrification in European forest soils. In: Carbon and nitrogen cycling in European forest ecosystems, E.-D. Schulze, (Ed.). Springer, Berlin, Germany. 297-331.

Piirainen, S., Finér, L. and Starr, M., 1998. Canopy and soil retention of nitrogen deposition in a mixed boreal forest in Eastern Finland. Water Air Soil Pollut., 105, 165-174.

Piirainen, S., Finér, L., Mannerkoski, M. and Starr, M., 2002a. Effects of forest clear-cutting on carbon and nitrogen fluxes through podzolic soil horizons. Plant Soil, 239, 301-311.

Piirainen, S., Finér, L. and Starr, M., 2002b. Deposition and leaching of sulphate and base cations in a mixed boreal forest in Eastern Finland. Water Air Soil Pollut., 131, 185-204.

Potila, H. and Sarjala, T., 2004. Seasonal fluctuation in microbial biomass and activity along a natural nitrogen gradient in drained peatland. Soil Biol. Biochem., 36, 1047-1055.

Postek, K.M., Driscoll, C., T., Aber, J.D. and Santore, R.C., 1995. Application of pnet-CN/CHESS to a spruce stand in Solling, Germany. Ecol. Model., 83, 163-172.

Qualls, R.G., 2000. Comparison of the behaviour of soluble organic and inorganic nutrients in forest soils. Forest Ecol. Manage., 138, 29-50.

Regina, K., Silvola, J. and Martikainen, P.J., 1998a. Mechanisms of $\mathrm{N}_{2} \mathrm{O}$ and $\mathrm{NO}$ production in the soil profile of drained and forested peatland, as studied with acetylene, nitrapyrin and dimethyl ether. Biol. Fertil. Soil, 27, 205-210.

Regina, K., Nykänen, H., Maljanen, M., Silvola, J. and Martikainen, P.J., 1998b. Emissions of $\mathrm{N}_{2} \mathrm{O}$ and $\mathrm{NO}$ and net nitrogen mineralization in a boreal forested peatland treated with different nitrogen compounds. Can. J. Forest Res., 28, 132-140.

Rekolainen, S., Posch, M., Kämäri, J. and Ekholm, P., 1991. Evaluation of accuracy and precision of annual phosphorous load estimates from two agricultural basins in Finland. J. Hydrol. 128, 237-255.
Rosén, K. and Lunmark-Thelin, A., 1987. Increased nitrogen leaching under piles of slash - a consequence of modern forest harvesting techniques. Scand. J. Forest Res., 2, 21-29.

Shreve, R.L., 1969. Stream lengths and basin areas in topographically random channel networks. J. Geol., 77, 397-414.

Skaggs, R.W., 1980. A water management model for artificially drained soils, North Carolina Agricultural Research Service, Raleigh, USA. 54pp.

Smolander, A., Kitunen, V., Priha, O. and Mälkönen, E., 1995. Nitrogen transformations in limed and nitrogen fertilized soil in Norway spruce stands. Plant Soil, 17, 107-115.

Smolander, A., Priha, O., Paavolainen, L., Steer, J. and Mälkönen, E., 1998. Nitrogen and carbon transformations before and after clear-cutting in repeatedly $\mathrm{N}$-fertilized and limed forest soil. Soil Biol. Biochem., 30, 477-490.

Staaf, H. and Berg, B., 1982. Accumulation and release of plant nutrients in decomposing Scots pine needle litter. Long-term decomposition in a Scots pine forest II. Can. J. Bot., 60, 15611568 .

Stednick, J.D., 1996. Monitoring the effects of timber harvest on annual water yield. J. Hydrol., 176, 79-95.

Tamm, C.O., 1991. Nitrogen in terrestrial ecosystems: questions of productivity, vegational changes and ecosystem stability. Ecol. Stud., 8, 115.

Teepe, R., Brumme, R. and Beese, F., 2000. Nitrous oxide emissions from frozen soils under agricultural, fallow and forest land. Soil Biol. Biochem., 32, 1807-1810.

Troendle, C.A., 1983. The potential for water yield augmentation from forest management in the Rocky Mountain region. Water Resour. Bull., 19, 359-373.

Titus, B.D. and Malcom, D.C., 1992. Nutrient leaching from litter layer after clearfelling Sitka spruce stands on peaty gley soils. Forestry, 65, 389-416.

Vestgarden, L.S., Selle, L.T. and Stuanes, A.O., 2003. In situ nitrogen mineralisation in a Scots pine (Pinus sylvestris L.) stand: effects of increased nitrogen input. Forest Ecol. Manage., 176, 205-216.

Wade, A.J., Durand, P., Beaujouan, V., Wessel, W.W., Raat, K.J., Whitehead, P.G., Butterfield,D., Rankinen, K., and Lepistö, A., 2002. A nitrogen model for European catchments: INCA, new model structure and equations. Hydrol. Earth Syst. Sci., 6, 559582.

Whitaker, A., Alila, Y., Beckers, J. and Toews, D., 2002. Evaluating peak flow sensitivity to clear-cutting in different elevation bands of a snowmelt-dominated mountainous catchment. Water Resour. Res., 38, 1172 doi:10.1029/2001WR000514.

Whitehead, P.G., Wilson, E.J. and Butterfield, D., 1998. A semidistributed Integrated Nitrogen model for multiple source assessment in Catchments (INCA): Part I - model structure and process equations. Sci. Total Envir., 210/211, 547-558.

Wright, R.F., Emmet, B.A. and Jenkins, A., 1998a. Acid deposition, land-use change and global change: MAGIC 7 model applied to Aber, UK (NITREX project) and Risdalsheia, Norway (RAIN and CLIMEX projects). Hydrol. Earth Syst. Sci., 2, 385-397.

Wright, R.F., Beier, C. and Cosby, B.J., 1998b. Effects of nitrogen deposition and climate change on nitrogen runoff at Norwegian boreal forest catchments: the MERLIN model applied to Risdalsheia (RAIN and CLIEMX projects). Hydrol. Earth Syst. Sci., 2, 399-414.

$\mathrm{Wu}, \mathrm{L}$. and McGechan, M.B., 1998. A review of carbon and nitrogen processes in four soil nitrogen dynamics models. $J$. Agr. Eng. Res., 69, 279-305. 